\title{
Cost Analysis of Power Plant Cooling Using Aquifer Thermal Energy Storage
}

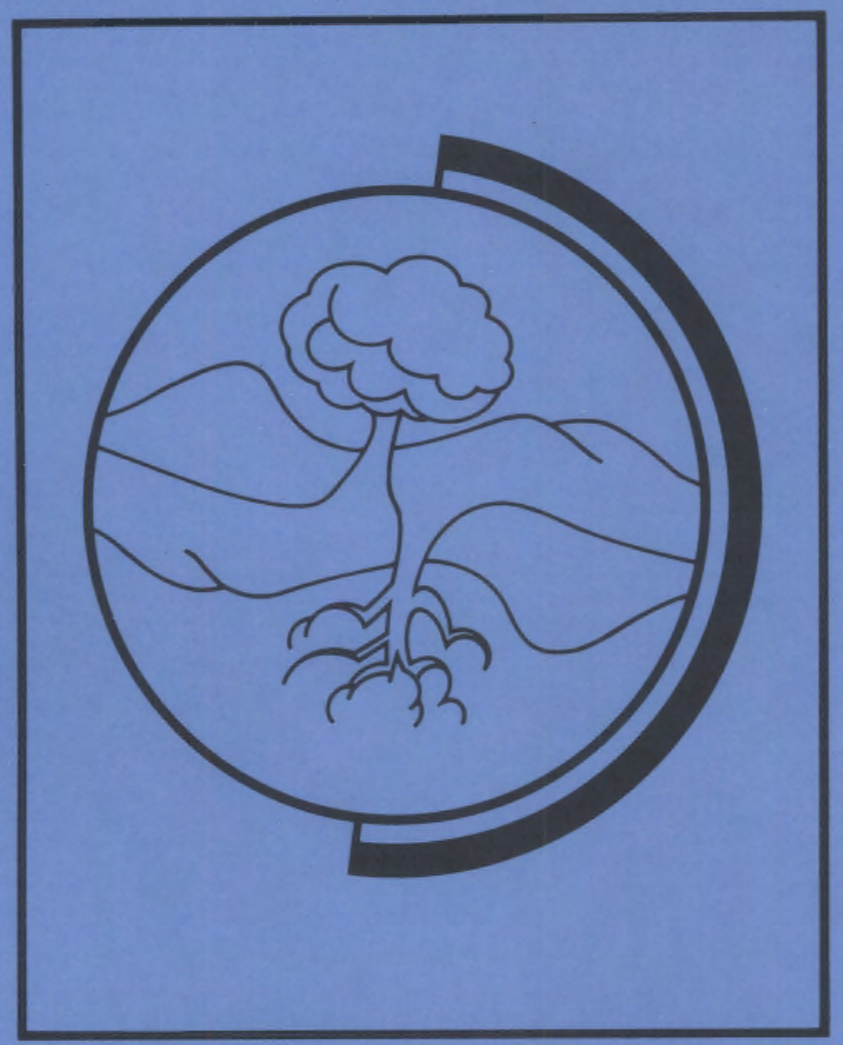

May 1989

Prepared for the U.S. Department of Energy under Contract DE-AC06-76RLO 1830

Pacific Northwest Laboratory

Operated for the U.S. Department of Energy by Battelle Memorial Institute 


\section{DISCLAIMER}

This report was prepared as an account of work sponsored by an agency of the United States Government. Neither the United States Government nor any agency thereof, nor Battelle Memorial Institute, nor any or their employees, makes any warranty, expressed or implied, or assumes any legal liability or responsibility for the accuracy, completeness, or usefulness of any information, apparatus, product, or process disclosed, or represents that its use would not infringe privately owned rights. Reference herein to any specific commercial product, process, or service by trade name, trademark, manufacturer, or otherwise does not necessarily constitute or imply its endorsement, recommendation, or favoring by the United States Government or any agency thereof, or Battelle Memorial Institute. The views and opinions of authors expressed herein do not necessarily state or reflect those of the United States Government or any agency thereof.

\section{PACIFIC NORTHWEST LABORATORY operated by \\ BATTELLE MEMORIAL INSTITUTE \\ for the \\ UNITED STATES DEPARTMENT OF ENERGY \\ under Contract DE-AC06-76RLO 1830}

\begin{tabular}{|c|c|}
\hline \multicolumn{2}{|c|}{ Printed in the United States of America } \\
\hline & $\begin{array}{l}\text { Available from } \\
\text { National Technical Information Service }\end{array}$ \\
\hline \multirow{2}{*}{\multicolumn{2}{|c|}{$\begin{array}{l}\text { National Technical Information Service } \\
\text { United States Department of Commerce }\end{array}$}} \\
\hline & \\
\hline \multicolumn{2}{|c|}{5285 Port Royal Road } \\
\hline \multicolumn{2}{|c|}{ Springfield, Virginia 22161} \\
\hline \multirow{2}{*}{\multicolumn{2}{|c|}{$\begin{array}{l}\text { NTIS Price Codes } \\
\text { Microfiche A01 }\end{array}$}} \\
\hline & \\
\hline \multicolumn{2}{|c|}{ Printed Copy } \\
\hline & Price \\
\hline Pages & Codes \\
\hline 001-025 & $\mathrm{A} 02$ \\
\hline 026-050 & A03 \\
\hline 051-075 & $\mathrm{A} 04$ \\
\hline 076-100 & A0S \\
\hline $101-125$ & A06 \\
\hline $126-150$ & $\mathrm{~A} 07$ \\
\hline 151-175 & A08 \\
\hline $176-200$ & A09 \\
\hline $201-225$ & A10 \\
\hline $226-250$ & A11 \\
\hline $251-275$ & A12 \\
\hline $276-300$ & A13 \\
\hline
\end{tabular}


COST ANALYSIS OF POWER PLANT COOLING

USING AQUIFER THERMAL ENERGY STORAGE

P. W. Zimmerman

M. K. Drost

May 1989

Prepared for

the U.S. Department of Energy

under Contract DE-AC06-76RL0 1830

Pacific Northwest Laboratory

Richland, Washington 99352 



\section{SUMMARY}

Most utilities in the U.S. experience their peak demand for electric power during periods with high ambient temperature. Unfortunately, the performance of many power plants decreases with high ambient temperature. The use of aquifer thermal energy storage (ATES) for seasonal storage of chill can be an alternative method for heat rejection. Cold water produced during the previous winter is stored in the aquifer and can be used to provide augmented cooling during peak demand periods increasing the output of many Rankine cycle power plants. This report documents an investigation of the technical and economic feasibility of using aquifer thermal energy storage for peak cooling of power plants.

The investigation consists of developing modeis that describe the performance of key power plant components such as the cooling tower, condenser, heat exchangers, and the aquifer system. The performance models are combined with cost models to calculate unit capital costs and energy costs for this concept.

In the study, seven cases are examined. The first is a "base" case to which the six others are compared. The six cases are variations on geographic location, desired condenser pressure, operation strategy, capital costs, and aquifer recovery temperature. Within each case, 15 combinations of cooling tower effectiveness and circulating water temperature range are considered. An optimum (minimum) cost is obtained for each combination. In general, it was found that costs decrease with increasing range and/or decreasing cooling tower effectiveness. These conditions would be encountered when the installed cooling tower was undersized or not performing up to design specifications.

The ATES power plant cooling augmentation system increases the output of the plant when the ATES system is in operation. The cost of the increased power production depends on the cost of the ATES system and the amount of increase in power production. For plants with a large cooling tower range and a cooling tower with poor performance (cooling tower effectiveness between 0.4 and 0.5 ), the ATES system produces relatively large energy savings. This 
results in a levelized energy cost, for the increased power production, of between 50 and $1000 \mathrm{mills} / \mathrm{kWh}$. Corresponding unit capital costs range between 100 and $1100 \$ / \mathrm{kwe}$. For cooling tower effectiveness in excess of 0.6 or cooling tower ranges less than $11^{\circ} \mathrm{C}$ (implying an appropriately sized or oversized cooling tower), levelized energy costs exceed $1000 \mathrm{mills} / \mathrm{kWh}$ and capital costs exceed $1100 \$ / \mathrm{kWe}$.

While it appears that the ATES system for peak power plant cooling can be economic for some situations, the applications will be limited to power plants with either undersized cooling towers or cooling towers that are not operating as designed. While not the subject of this study, dry cooled plants may be a more attractive application because of the Iarge performance penalt. associated with operating an all dry cooling tower at high ambient temperatures. 


\section{CONTENTS}

SUMMARY ............................... $i i_{i}$

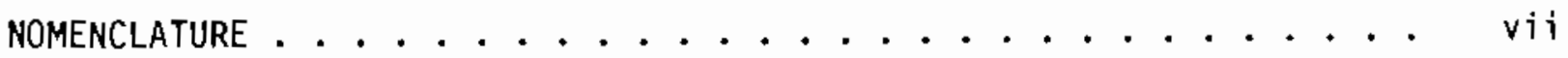

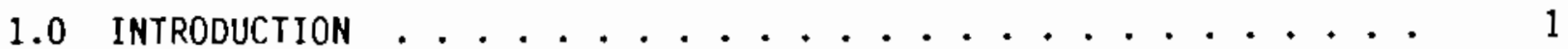

2.0 CONCEPT DESCRIPTION ....................... 3

3.0 MOOEL DEVELOPMENT . . . . . . . . . . . . . . 7

3.1 EQUATIONS AND DEFINITIONS .............. 7

3.1 .1 Cooling Tower Model ............. . 7

3.1 .2 Power Plant Model . . . . . . . . . . . 8

3.1 .3 Heat Exchanger Model ............. 9

3.2 DETERMINATION OF ENERGY OUTPUT WITH AND WITHOUT ATES . . . 9

3.3 SIZING ATES EQUIPMENT ................... 11

3.3.1 Heat Exchanger Sizing............ 11

3.3 .2 Day Tank Sizing............... 13

3.3 .3 Number of wells ............. 13

3.4 ATES SYSTEM COSTS . . . . . . . . . . . . 14

3.4.1 Capital Costs ................ 14

$3.4 .20 \& M$ Costs ................. 16

3.4.3 Levelized Energy Costs and Unit Capital Costs . . . 16

4.0 SELECTION OF CASES . . . . . . . . . . . . 19

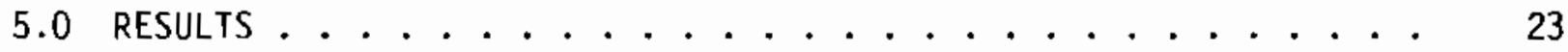

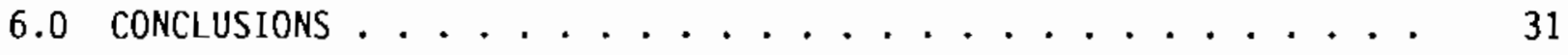

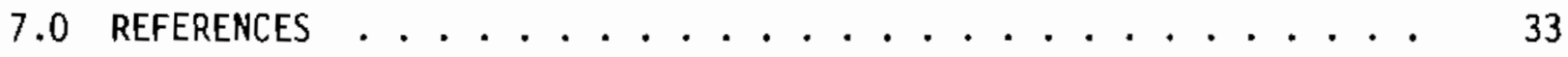

APPENDIX A - POWER PLANT CAPACITIES FROM LICENSEO OPERATING REACTORS,

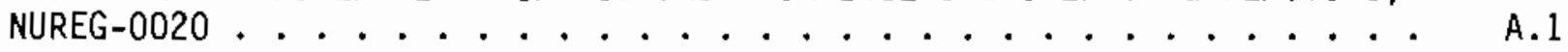

APPENDIX B - WET-BULB TEMPERATURE DURATION DATA FOR TWO SITES . . . B. B 


\section{FIGURES}

2.1 ATES Power Plant Cooling Augmentation System, Cooling Augmentation Phase .............. 4

2.2 ATES Power Plant Cooling Augmentation System, Heat Rejection Phase................. 5

2.3 Well Layout Design and Routing of Fluid Transmission Lines . . . 6

5.1 Comparison of Levelized Energy Cost of Base Case and Case 2 . . . 25

5.2 Comparison of Unit Capital Cost of Base Case and Case 2 . . . 25

5.3 Comparison of Levelized Energy Cost of Base Case and Case 8 . . . 25

5.4 Comparison of Unit Capital Cost of Base Case and Case $8 \ldots 26$

5.5 Comparison of Levelized Energy Cost of Base Case and Case 3 . . 27

5.6 Comparison of Unit Capital Cost of Base Case and Case $3 \ldots 2$ ?

5.7 Comparison of Levelized Energy Cost of Base Case and Case 5 . . . 28

5.8 Comparison of Unit Capital Cost of Base Case and Case 5 . . . . 28

5.9 Comparison of Levelized Energy Cost of Base Case and Case $6 . .29$

5.10 Comparison of Unit Capital Cost of Base Case and Case $6 \ldots 29$

5.11 Comparison of Levelized Energy Cost of Base Case and Case 7 . . 30

5.12 Comparison of Unit Capital Cost of Base Case and Case $7 \ldots 3$ C

\section{$\underline{\text { TABLES }}$}

3.1 Data for Middletown Plant . . . . . . . . . . . . . . 11

3.2 Cost Sumnary (a), 1987 Dollars . . . . . . . . . . 15

4.1 variations Studied ................ 20

4.2 Hours Above $3.5 \mathrm{in.} \mathrm{Hg}$ in Middletown .......... 21

4.3 Hours Above $2.5 \mathrm{in.} \mathrm{Hg}$ in Middletown .......... 21 


\section{NOMENCLATURE}

A Heat exchanger heat transfer area [ $\left.\mathrm{m}^{2}\right]$

CC Capital cost [\$]

$\mathrm{C}_{\mathrm{p}} \quad$ Specific heat of water $\left[\mathrm{MJ} /\left(\mathrm{kg}-{ }^{\circ} \mathrm{C}\right)\right]$

CTTD Condenser terminal temperature difference $\left[{ }^{\circ} \mathrm{C}\right]$

E Electrical energy produced without ATES [MWh]

EFFECT Cooling tower effectiveness [p.u.]

EFFIC Gross cycle efficiency [p.u.]

ELEC Annual cost of electricity for pumps and fans [\$/year]

FCR Fixed charge rate

$\mathrm{H} \quad$ Number of hours at a wet-bulb temperature [hr]

HEAD Pressure drop that pump must overcome $[\mathrm{kJ} /(\mathrm{kg}-\mathrm{sec})]$

HOURA Number of hours of operation per day [hr/day]

i Index

LEC Levelized energy cost [\$/MWh]

$\dot{m}_{\mathrm{cw}}$ Mass flow rate of circulating water $[\mathrm{kg} / \mathrm{sec}]$

$m_{\text {ad }}$ Mass flow rate from the aquifer during discharge $[\mathrm{kg} / \mathrm{hr}]$

$m_{r d t}$ Mass flow rate through heat exchanger $[\mathrm{kg} / \mathrm{hr}]$

$\dot{m}_{w}$ Mass flow rate per well $[\mathrm{kg} / \mathrm{hr}]$

$\mathrm{n}$ Maximum value of index

NELL Number of wells

0\&M Annual operation and maintenance cost [\$/year]

$P_{E} \quad$ Gross electricity power output [MW] 


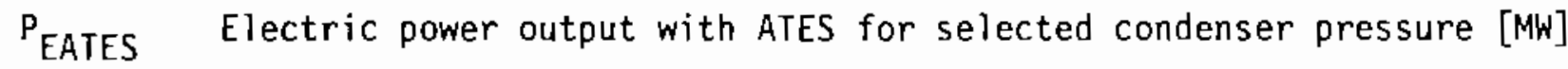
PEFF Puinp and motor efficiency [p.u.]

$P_{E P} \quad$ Electric power output of plant without ATES at maximum welt-bulb temperature $[\mathrm{MW}]$

$P_{E S}$ Gross electric power output after load shedding [MW]

POW Pumping power [ $\mathrm{kW}]$

Heat rejection rate to aquifer [MW]

$\dot{Q}_{\mathrm{C}}$

$\dot{Q}_{\text {CTDES }}$

Heat rejection rate by cooling tower [MW]

Desired heat rejection rate [MW]

$\dot{Q}_{\text {IN } \quad \text { Cycle heat input rate [MW] }}$

$\dot{Q}_{R J} \quad$ cycle heat rejection rate [MW]

$\dot{Q}_{R J S}$

Cycle heat rejection rate during load shedding [MW]

Q RJMAX

Cycle heat rejection rate at maximum condenser pressure [MW]

RANGE Cooling tower range $\left[{ }^{\circ} \mathrm{C}\right]$

RHO Density of water $\left[\mathrm{kg} / \mathrm{m}^{3}\right]$

$T_{\text {adh }}$ Temperature at aquifer inlet during summer $\left[{ }^{\circ} \mathrm{C}\right]$

Tade Temperature at aquifer outlet during summer $\left[{ }^{\circ} \mathrm{C}\right]$

$T_{\text {AWB }}$ Ambient wet-bulb temperature $\left[{ }^{\circ} \mathrm{C}\right]$

${ }^{\mathrm{T}} \mathrm{CI}$ Temperature of circulating water at condenser inlet $\left[{ }^{\circ} \mathrm{C}\right]$

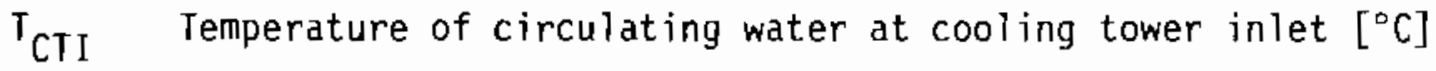

${ }^{\top}$ Сто Temperature of circulating water at cooling tower out Tet $\left[{ }^{\circ} \mathrm{C}\right]$

${ }_{\text {EXX }} \quad$ Temperature at turbine exhaust $\left[{ }^{\circ} \mathrm{C}\right]$

TIME Total summer operating time [hr]

$\mathrm{T}_{\text {lm }} \quad$ Log mean temperature difference $\left[{ }^{\circ} \mathrm{C}\right]$

$U$ Overall heat transfer coefficient of heat exchanger $\left[\mathrm{MJ} /\left(\mathrm{m}^{2}-\mathrm{sec}-{ }^{\circ} \mathrm{C}\right)\right.$. 
UCC Unit capital cost [\$/kWe]

$V_{D T} \quad$ volume of day tank $\left[\mathrm{m}^{3}\right]$

WPPSS Washington Public Power Supply System 

COST ANALYSIS OF POWER PLANT COOLING USING AQUIFER THERMAL ENERGY STORAGE

\subsection{INTRODUCTION}

Most utilities in the United States experience their peak demand for electric power during periods with high ambient temperature. Unfortunately, the performance of many power plants decreases with high ambient temperature. A review of Licensed Operative Reactors, NUREG-0020 (U.S. Nuclear Regulatory Commission 1987) showed that, on average, nuclear power plant output is lower than rated capacity by $2 \%$ or 17.9 MWe per plant. (See Appendix A.) This results in a total deficit of 1668 MWe for 93 plants. The worst case is the Grand Gulf nuclear power plant, which produces 142 MWe or $11 \%$ under its rated capacity. If we assume that oil and coal-fired plants suffer the same capacity reduction and recognize that nuclear power is approximately $10 \%$ of the nation's generating capacity, there is a 16,680 MWe capacity reduction nationwide.

It is reasonable to assume that oil and coal plants can be included in this estimate because NUREG-0020 attributes the capacity reduction to seasonal limitations. The seasonal limitation is experienced in the sumnertime when the heat sink (atmosphere, river, lake, ocean) temperature is high. The high heat sink temperature causes the plant to operate at a lower thermodynamic efficiency, which reduces output. For example, a 650-MWe plant with evaporative cooling can experience a 5.1-MWe capacity reduction for a $5^{\circ} \mathrm{C}$ increase in wet-bulb temperature. Coincidentally, the reduced output occurs during the high-demand period for utilities, that is, during summer afternoons.

The aquifer thermal energy storage (ATES) concept offers the potential of rejecting heat at a lower temperature, which would increase plant capacity during high demand periods without adding additional generating capacity. This is accomplished by storing water, cooled during winter, for use in power plant cooling during times with high ambient temperature.

The benefit of storing or rejecting energy to underground water tables, also known as aquifers, has been recognized and exploited. For example, the 
Shippingport nuclear power station mixed cold well water with river water to obtain additional cooling capacity and avoided the cost of replacing heat exchangers. The technology associated with ATES is developing rapidly with a number of field tests in progress in the United States and overseas.

The objective of this activity is to perform a scoping study that will investigate the feasibility of using ATES for power plant cooling augmentation. The scoping study is 1 imited to retrofit application of ATES systems to power plants with evaporative cooling towers. Application of ATES to dry cooling towers or to river, lake, or ocean nonevaporative cooling towers may be viable alternatives but are not included. Use of ATES systems in new construction may allow smaller cooling towers, but this alternative is beyond the scope $0^{=}$ this study.

The concept of applying ATES to power plant cooling is described in Section 2.0, followed by descriptions of thermal and cost models in Section 3.0. The cases selected for analysis are shown in Section 4.0, with results presented in Section 5.0. Finally, conclusions are presented in Section 6.0. 


\subsection{CONCEPT DESCRIPTION}

The ATES power plant cooling augmentation system stores winter-cooled water in natural aquifers for use during the summer, when ambient temperatures are higher. During the winter, water is drawn from wells into a cooling tower, where it is chilled by the cool ambient temperatures, then injected into the aquifer again, which sustains the cool temperatures until the water is needed for summertime use. Then, it is recovered from the aquifer in the summer and placed in a day tank, from which it is drawn into a heat exchanger to reduce the temperature of cooling water coming from the power plant's condenser. The routing of water from the wells to the cooling tower, day tank, heat exchanger, and condenser varies depending on the phase of operation, i.e., whether the system is in the cooling augmentation phase (summer) diagrammed in Figure 2.1, or the heat rejection phase (winter) in Figure 2.2.

During the cooling augmentation phase in summer, winter-chilled water is continuously withdrawn (24 hours per day) from the aquifer to a day tank. When peak demand coincides with hot weather, the day tank water is circulated through a heat exchanger that cools the condenser cooling water, allowing the condenser to operate at a lower pressure. The purpose of the day tank is to allow a reduced number of wells. The rate of flow from the aquifer determines the number of wells. Without a day tank, six times more wells would be required to meet the peak flow. The day tank has a capacity sufficient to provide cooling for a 4- to 6-hour period. The warmed day tank water is also pumped continuously back to the injection wells. The day tank is arranged to form a thermocline with cold water on the bottom and heated water on the top. Thus, the day tank always has the same amount of water but with a varying ratio of cold to heated water. A heat exchanger is included in the design to prevent mixing of chemically balanced circulating water with untreated aquifer water and to avoid putting treated water back into the aquifer. Thus, the only environmental impact will be caused by heating and cooling the aquifer.

In winter (Figure 2.2), the day tank and heat exchanger are in standby. Because plant cooling tower capacity exceeds plant cooling requirements in the winter, it is assumed that one or more cells of the cooling tower could be 


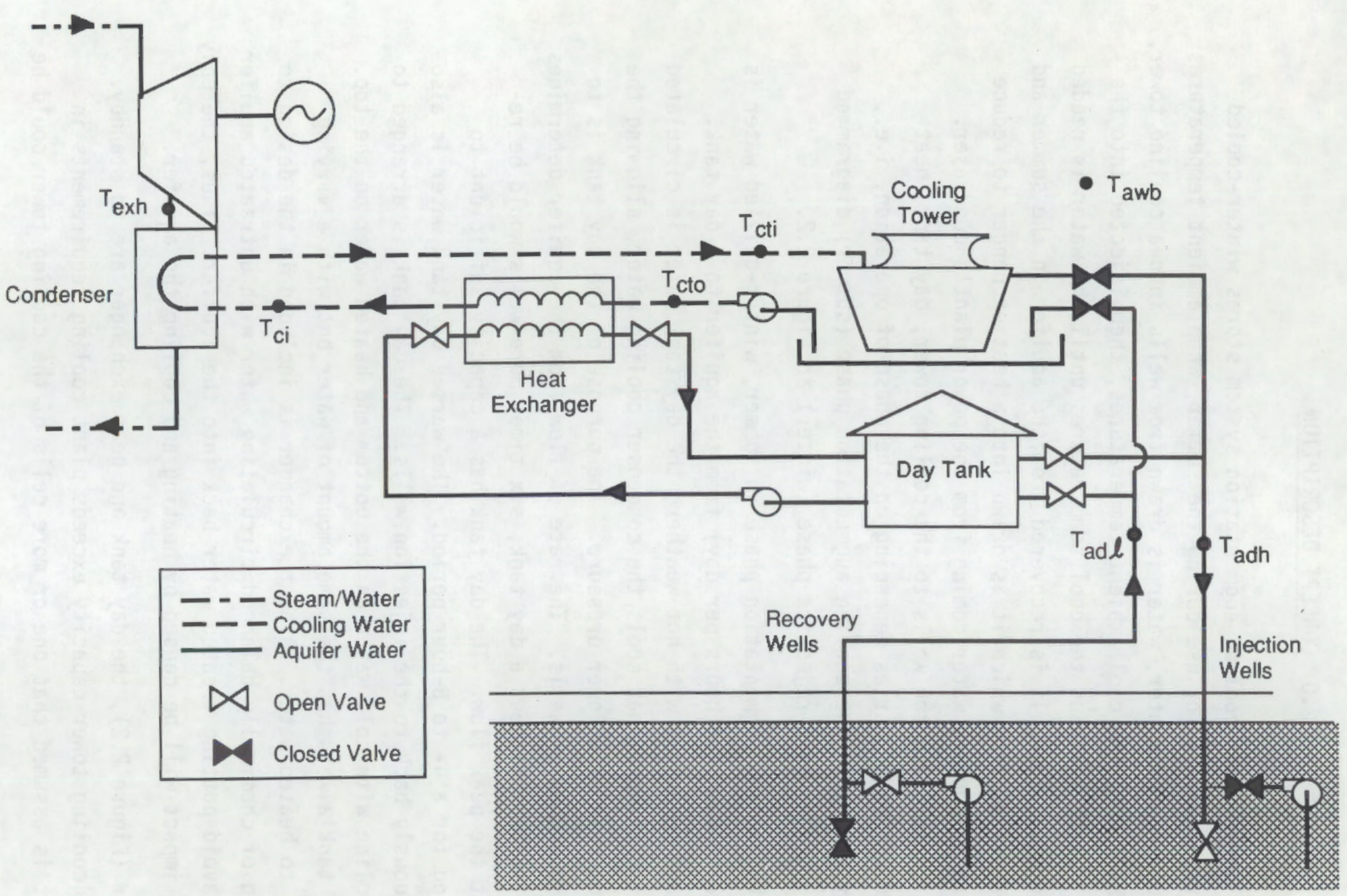

FIGURE 2.1. ATES Power Plant Cooling Augmentation System, Cooling Augmentation Phase 


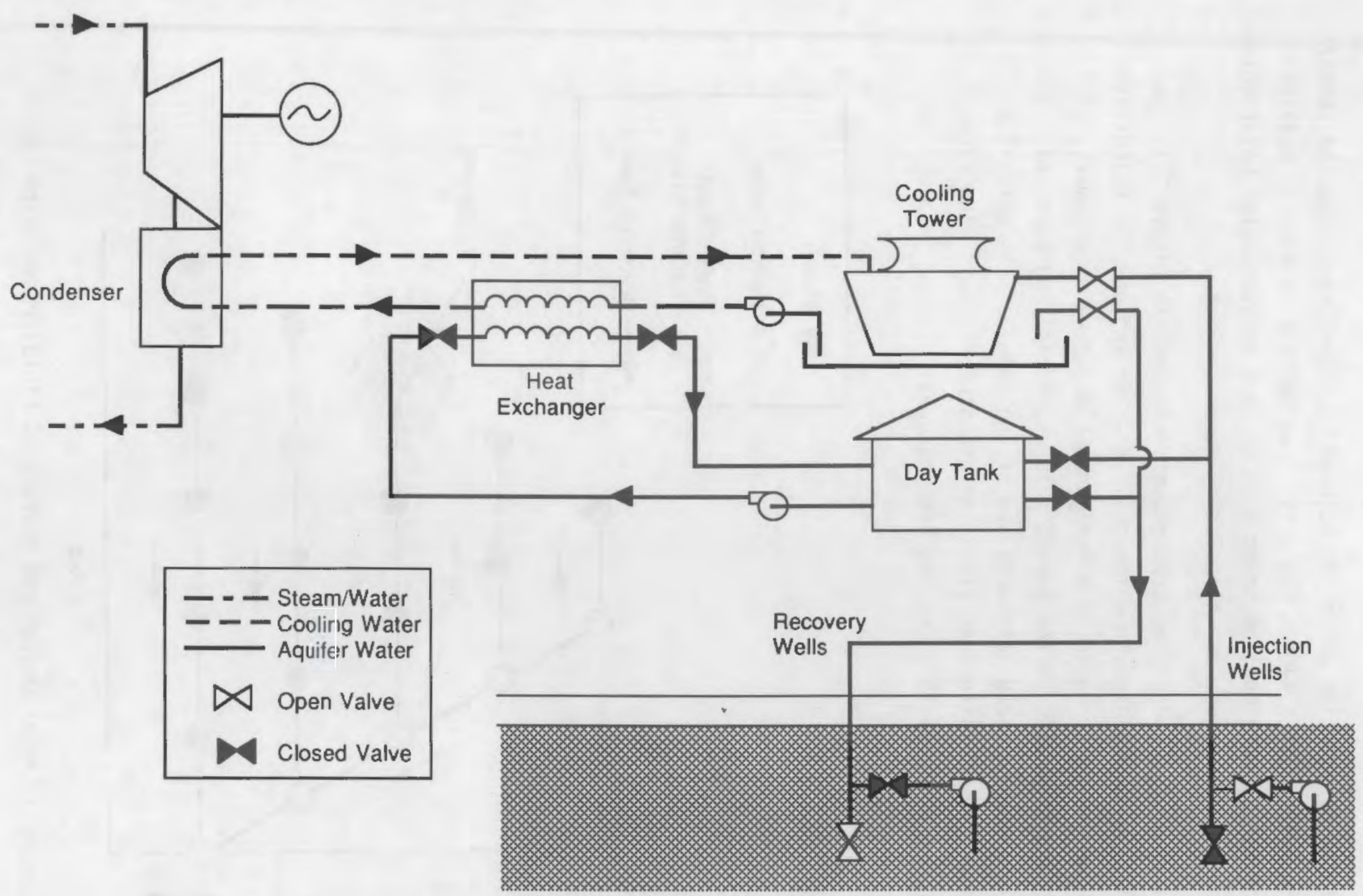

FIGURE 2.2. ATES Power Plant Cooling Augmentation System, Heat Rejection Phase 
isolated from the circulating water and be used to reject heat from the summerwarmed aquifer water. This avoids the cost of an additional aquifer cooling tower. The cell(s) of the cooling tower used to cool aquifer water may require cleaning before continued use for circulating water cooling.

The aquifer layout and piping arrangement are shown in Figure 2.3. Two identical well fields are used, one for chill storage and one for reject heat storage. The wells are arranged in a hexagonal close-pack arrangement, and piping connecting the wells to the manifold is orthogonal and parallel. This layout minimizes the required land area and piping length. The well flow rate and spacing is very site-specific. In this study, a well flow rate of $1000 \mathrm{gpm}$ with a spacing of 15 acres has been assumed.

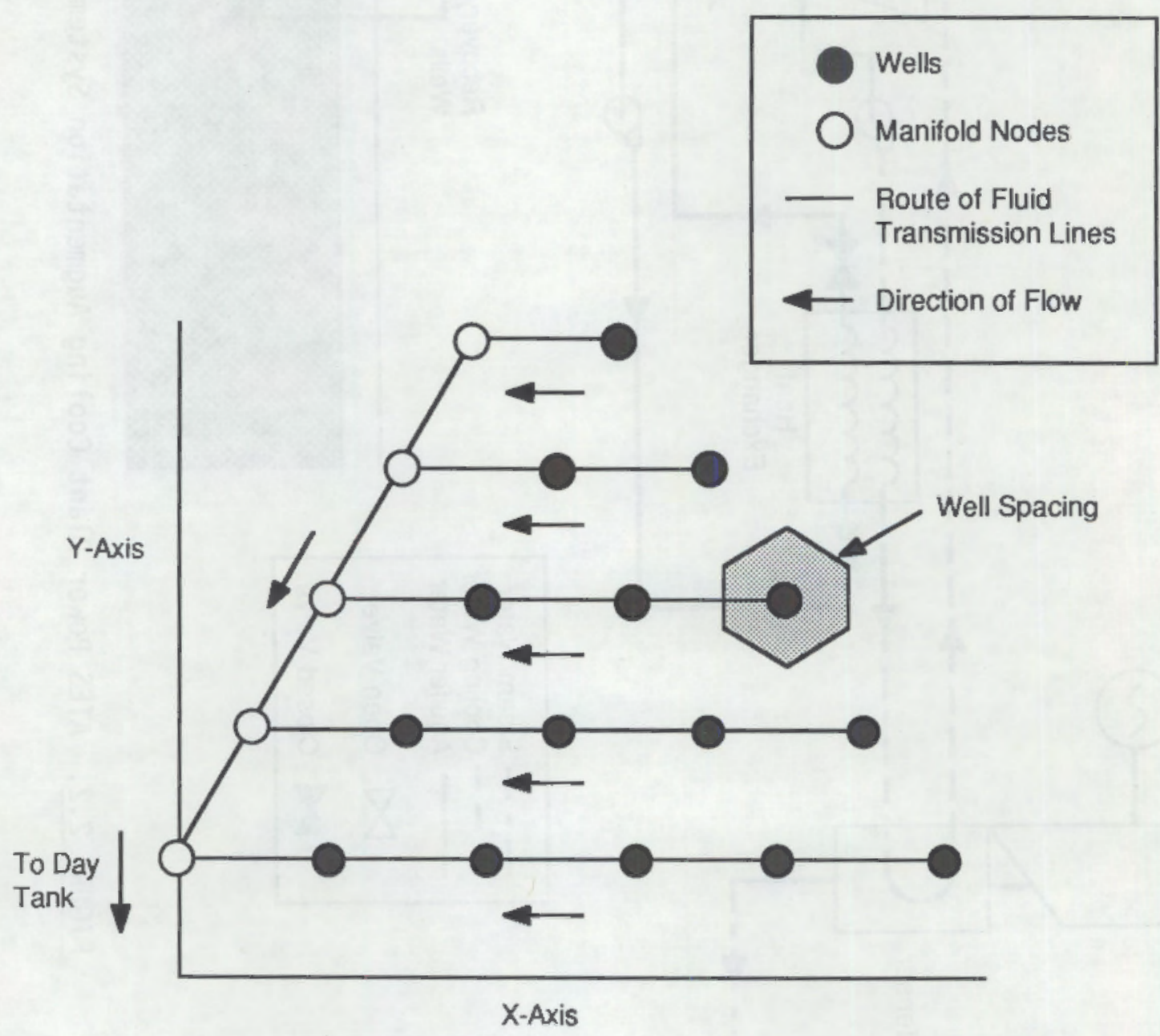

FIGURE 2.3. Well Layout Design and Routing of Fluid Transmission Lines 


\subsection{MODEL DEVELOPMENT}

The objective of this study is to conduct a feasibility analysis; therefore, simple models were developed. Models were developed only for summer operation. Winter conditions were not modeled because summer operation determined the key design parameters. The equations and definitions are introduced, then the derivations of relationships used for determining energy output, component sizes, and component costs are presented. The energy output is based on the Middletown plant (Drost and Johnson 1980) and costs are from Brown (1983).

\subsection{EQUATIONS AND DEFINITIONS}

The equations used are taken from heat exchanger theory and basic energy balance equations. The equations are presented without derivation.

\subsubsection{Cooling Tower Model}

Cooling tower effectiveness is the ratio of the amount of heat transferred to the amount of heat that could be transferred with infinite surface area, and can be expressed as a ratio of temperature differences (Welty, Wicks, and Wilson 1976; Kays and London 1964). For an evaporative cooling tower (Figures 2.1 and 2.2), the effectiveness is

$$
\text { EFFECT }=\left(T_{\text {CTI }}-T_{C T O}\right) /\left(T_{C T I}-T_{A W B}\right) \quad[\text { p.u.] }
$$

where EFFECT $=$ cooling tower effectiveness [p.u.]

${ }_{C T I}=$ circulating water temperature entering cooling tower $\left[{ }^{\circ} \mathrm{C}\right]$

${ }_{\text {Сто }}=$ circulating water temperature leaving cooling tower $\left[{ }^{\circ} \mathrm{C}\right]$

$\mathrm{T}_{\text {AWB }}=$ ambient wet-bulb temperature $\left[{ }^{\circ} \mathrm{C}\right]$.

The range is defined as the temperature range of the circulating water

$$
\text { RANGE }=T_{C T I}-T_{C I} \quad\left[{ }^{\circ} \mathrm{C}\right]
$$

where ${ }_{C I}$ equals circulating water temperature entering the condenser $\left[{ }^{\circ} \mathrm{C}\right]$. 
Heat exchanger terminal temperature difference is the temperature difference between the two streams leaving the heat exchanger. For the condenser (Figures 2.1 and 2.2), this parameter is

$$
\text { CTTD }=T_{E X H}-T_{C T I}
$$

where CTTO is condenser terminal temperature difference $\left[{ }^{\circ} \mathrm{C}\right]$ and $\mathrm{T}_{\text {EXH }}$ is turbine exhaust or condenser temperature $\left[{ }^{\circ} \mathrm{C}\right]$. Heat losses from the circulating water pipe and condenser are neglected as well as subcooling effects.

\subsubsection{Power Plant Model}

The power plant efficiency used in this study is the gross cycle efficiency, which ignores cycle electrical parasitics.

$$
\text { EFFIC }=P_{E} / \dot{Q}_{I N} \quad \text { [P.u.] }
$$

where $\quad E F F I C=$ gross cycle efficiency [p.u.]

${ }^{P_{E}}=$ gross electricity power output [MW]

$Q_{I N}=$ cycle heat input rate $[\mathrm{MW}]$

and

$$
\dot{Q}_{I N}=P_{E}+\dot{Q}_{R J}
$$

where $\dot{Q}_{R J}$ is cycle heat rejection rate $[M W]$.

Substituting Equation (3.5) into (3.4) and solving for $\dot{Q}_{R J}$ yields

$$
\dot{Q}_{R J}=P_{E}(1 / E F F I C-1.0) \quad[M W]
$$




\subsubsection{Heat Exchanger Model}

The ATES heat exchanger (Figures 2.1 and 2.2) is sized using the $\log$ mean temperature difference approach:

$$
\dot{Q}_{A T E S}=U(A) T_{\ell m}
$$

where $\quad U=$ overall heat transfer coefficient $\left[\mathrm{MJ} /\left(\mathrm{m}^{2}-\mathrm{sec}-{ }^{\circ} \mathrm{C}\right)\right]$

$$
\begin{aligned}
A & =\text { heat transfer area }\left[\mathrm{m}^{2}\right] \\
\dot{Q}_{\text {ATES }} & =\text { heat rejected to aquifer }[\mathrm{MW}]
\end{aligned}
$$

and

$$
T_{\ell m}=\frac{\left(T_{C T O}-T_{a d h}\right)-\left(T_{C I}-T_{a d \ell}\right)}{\ln \left[\left(T_{C T O}-T_{a d h}\right) /\left(T_{C I}-T_{a d \ell}\right)\right]} \quad\left[{ }^{\circ} \mathrm{C}\right]
$$

where $T_{\ell m}=\log$ mean temperature difference $\left[{ }^{\circ} \mathrm{C}\right]$

$$
\begin{aligned}
& \mathrm{T}_{\mathrm{adh}}=\text { temperature of heated water to aquifer }\left[{ }^{\circ} \mathrm{C}\right] \\
& \mathrm{T}_{\mathrm{adl}}=\text { temperature of cool water from aquifer }\left[{ }^{\circ} \mathrm{C}\right] .
\end{aligned}
$$

\subsection{DETERMINATION OF ENERGY OUTPUT WITH AND WITHOUT ATES}

Plant output with ATES is constant because the ATES system maintains a selected condenser temperature during the period that the ATES system is in use. Plant output without ATES will vary as the ambient wet-bulb temperature varies. Therefore, a relationship that provides the condenser temperature as a function of ambient wet-bulb temperature is needed.

Without ATES, the temperature of the circulating water leaving the cooling tower equals the temperature of the circulating water entering the condenser, or

$$
T_{\text {CTO }}=T_{C I}
$$


Therefore, the numerator of Equation (3.1) can be replaced with the range from Equation (3.2) and solved for $\mathrm{T}_{\mathrm{CTI}}$. Substituting that expression for ${ }^{T} \mathrm{CTI}$ into Equation (3.3) and solving yields the desired relationship for the condenser temperature.

$$
T_{E X H}=(\text { RANGE/EFFECT })+C T T D+T_{A W B} \quad\left[{ }^{\circ} \mathrm{C}\right]
$$

If conditions result in a condenser temperature in excess of the maximum allowable for the given turbine design, electricity production is reduced (load shedding to prevent turbine damage) to maintain the condenser at the maximum allowable temperature. The determination of power output after load shedding is given by Equation (3.11) where Equation (3.6) has been solved for $P_{E}$, and the variables subscripted with an " $S$ " to denote load shedding conditions:

$$
P_{E S}=\dot{Q}_{R J S} /(1 / E F F I C S-1.0)
$$

Determination of $P_{E S}$ (power output after load shedding) requires information on the reject heat and efficiency. The efficiency is assumed to be the cycle efficiency at the maximum temperature. The actual efficiency is somewhat less due to part-load characteristics of the turbine, but this is neglected in this study. The reject heat is found from a heat balance assuming constant circulating water flow rate and specific heat:

$$
\dot{Q}_{\text {RJS }}=\dot{Q}_{\text {RJMAX }}\left[\left(T_{C T I}-T_{C T O}\right) / \text { RANGE }\right] \quad[M W]
$$

where $\dot{Q}_{R J M A X}$ equals heat rejection rate [MW] from Table 3.1 , and $T_{C T I}$ and ${ }^{\mathrm{T}}$ CTO are determined from Equations (3.3) and (3.1), respectively.

The electrical energy output is obtained by multiplying the power level $\left(P_{E}\right.$ and $\left.P_{E S}\right)$ by $H_{1}$ the number of hours at the corresponding ambient temperature 
TABLE 3.1. Data for Middletown Plant

\begin{tabular}{ccccc}
$\begin{array}{c}\text { Condenser } \\
\text { Pressure, } \\
\text { in. } \mathrm{Hg}\end{array}$ & $\begin{array}{c}\text { Condenser } \\
\text { Temperature, } \\
{ }^{\circ} \mathrm{C}\left(T_{\mathrm{EXH}}\right)\end{array}$ & $\begin{array}{c}\text { Gross Electric } \\
\text { Output, } \\
\text { MWe }\left(P_{\mathrm{E}}\right)\end{array}$ & $\begin{array}{c}\text { Cycle Heat } \\
\text { Input Rate, } \\
\text { MWth }\left(\dot{Q}_{\mathrm{IN}}\right)\end{array}$ & $\begin{array}{c}\text { Cycle Heat } \\
\text { Rejection Rate, } \\
\text { MWth }\left(\dot{Q}_{\mathrm{RJ}}\right)\end{array}$ \\
\cline { 1 - 3 } & 42.5 & 657 & 1534 & 876 \\
3.5 & 46.1 & 653.8 & 1534 & 880 \\
3.5 & 49.2 & 650 & 1534 & 884 \\
4.0 & 51.9 & 645.3 & 1534 & 888 \\
4.5 & 54.4 & 640.1 & 1534 & 893.6 \\
5.0 & 56.7 & 634.4 & 1534 & 899.3
\end{tabular}

oil. The energy is summed for all ambient temperature increments up to the number of hours of operation assumed for ATES:

$$
E=\sum_{i=1}^{n} P_{E i} * H_{i}+\sum_{j=n+1}^{m} P_{E S j} * H_{j} \quad[M W h]
$$

The hours corresponding to wet-bulb temperatures [temperature duration curves from Drost and Johnson (1980) and Pacific Northwest Laboratory (1984)] are tabulated in Appendix $B$ for the three locations considered in this study.

Table 3.1 provides the relationship of plant parameters to condenser temperature for a $650 \mathrm{MW}$, Middletown, U.S.A., nuclear power plant (Drost and Johnson 1980). To avoid turbine damage, the turbine is not allowed to exceed backpressure of $5 \mathrm{in}$. $\mathrm{Hg}$.

\subsection{SIZING ATES EQUIPMENT}

Equipment sizes were required to develop concept cost estimates.

\subsubsection{Heat Exchanger Sizing}

Heat exchanger area is obtained from Equation (3.7), which requires determination of the maximum heat rejection rate to the aquifer and $T_{\ell m}$. The maximum heat rejection rate to the aquifer $\left(\dot{Q}_{A T E S}\right)$ is the difference between 
the heat rejection rate required to maintain the selected condenser conditions and the heat rejection rate by the cooling tower at maximum wet-bulb temperature, or

$$
\dot{Q}_{\text {ATES }}=\dot{Q}_{\text {CTDES }}-\dot{Q}_{C T} \quad[M W]
$$

where $\dot{Q}_{C T D E S}$ is the desired heat rejection rate and $\dot{Q}_{C T}$ is the heat rejection rate by the cooling tower.

The amount of heat rejected by the cooling tower is

$$
\dot{Q}_{C T}=\dot{\pi}_{C W} C_{p}\left(T_{C T I}-T_{C T O}\right) \quad[\mathrm{MW}]
$$

where $\dot{m}_{c w}$ equals the mass flow rate of circulating water and $C_{p}$ is the specif $c$ heat of circulating water $\left[\mathrm{MJ} /\left(\mathrm{kg}-{ }^{\circ} \mathrm{C}\right)\right]$.

The amount of heat rejected to maintain desired condenser conditions is

$$
\dot{Q}_{C T D E S}=\dot{m}_{C W} C_{p}\left(T_{C T I}-T_{C I}\right) \quad[\mathrm{MW}]
$$

Equation (3.17) is obtained by combining Equations (3.15) and (3.16) to eliminate $\dot{m}_{C W} c_{P}$ and obtain $\dot{Q}_{C T}$ in terms of $\dot{Q}_{C T D E S}$, then substituting for $\dot{Q}_{C T}$ in Equation (3.14) and using Equation (3.2).

$$
\dot{Q}_{\text {ATES }}=\dot{Q}_{\text {CTDES }}\left[1.0-\left(T_{\text {CTI }}-T_{\text {CTO }}\right) / \text { RANGE }\right] \quad[\mathrm{MW}]
$$

where $\dot{Q}_{\text {CTDES }}$ is taken from Table 3.1 for the desired condenser conditions.

For combinations of range, effectiveness, CTTD, and $T_{\text {ade }}$, heat exchanger area and cost will depend on the choice of heated water return temperature $\left(T_{a d h}\right)$. The value of $T_{\text {adh }}$ can result in small heat exchanger and high flow or large heat exchanger and low flow, with flow rate determining pumping costs and day tank costs. Thus, a range of values of $T_{\text {adh }}$ was considered to find the lowest cost system for each range/effectiveness combination.

The temperatures needed to obtain the log mean temperature difference in Equation (3.8) are obtained as follows. When the ATES system is operating, 
the condenser temperature is held at its selected value. Thus, using an assumed value for CTTD. Equation (3.3) yields $\mathrm{T}_{\text {CTI }}$. Equation (3.1) yields $\mathrm{T}_{\text {CTO }}$ for assumed values of cooling tower effectiveness and maximum wet-bulb temperature. The last unknown is the aquifer water temperatures. Results were calculated for Middletown and Jacksonville, Florida. Therefore, average aquifer recovery temperatures were assumed for both sites $\left(3.00^{\circ} \mathrm{C}\right.$ for Middletown and $6.67^{\circ} \mathrm{C}$ for Jacksonville).

\subsubsection{Day Tank Sizing}

The volume of the day tank depends on the flow rate through the heat exchanger and the number of hours per day of operation:

$$
V_{D T}=(1.1) \dot{m}_{r d t}(24-H O U R A) / R H O \quad\left[m^{3}\right]
$$

where $\quad 1.1=10 \%$ oversizing

$$
\begin{aligned}
\text { HOURA } & =\text { number of hours per day of operation }[\mathrm{hr}] \\
\text { RHO } & =\text { density of water }\left[\mathrm{kg} / \mathrm{m}^{3}\right] \\
24 & =\text { number of hours per day } \\
\dot{m}_{\mathrm{rdt}} & =\text { mass flow rate through heat exchanger }[\mathrm{kg} / \mathrm{hr}] \\
\mathrm{V}_{\text {DT }} & =\text { volume of day tank }\left[\mathrm{m}^{3}\right] .
\end{aligned}
$$

The mass flow is

$$
\dot{m}_{r d t}=3600 \dot{Q}_{A T E S} /\left[C_{p}\left(T_{a d l}-T_{a d h}\right)\right] \quad[\mathrm{kg} / \mathrm{h}]
$$

\subsubsection{Number of Wells}

The number of wells is determined from the required flow rate to fill the day tank and the unit production per well. Because the day tank is filled over a 24-hour period, the flow rate to fill it is

$$
\dot{m}_{\mathrm{ad}}=\dot{m}_{\mathrm{rdt}}(\text { HOURA }) / 24 \quad[\mathrm{~kg} / \mathrm{h}]
$$

where $\dot{m}_{a d}$ is the mass flow rate from aquifer to the day tank during discharge. 
The number of wells required is then

$$
N_{W E L L}=\dot{m}_{a d} / \dot{m}_{W} \quad[p . u .]
$$

where $\dot{m}_{w}$ is unit production $(\mathrm{kg} / \mathrm{h})$ per well. (Value assumed for this study is $227.060 \mathrm{~kg} / \mathrm{h}$ or $1000 \mathrm{gpm}$.$) The ratio \mathrm{N}_{W E L L}$ is always rounded to the next highest integer, then doubled to account for both injection and recovery wel] fields.

\subsection{ATES SYSTEM COSTS}

The ATES system costs consist of capital costs and operation and maintenance (08M) costs, as summarized in Table 3.2.

\subsubsection{Capital Costs}

The total well cost, heat exchanger cost, and day tank costs are obtaines by multiplying assumed unit costs to the size parameters obtained in Section 3.3. The interconnecting piping and 08M depend on many factors. From Brown (1983), the costs per well of these items were obtained for 2.0, 5.0, and 20.0 MWth aquifer chill storage systems. It was desired to have costs for $1000-\mathrm{gpm}$ wells with a 15-acre spacing (Figure 2.3). However, Brown (1983) reported results for wells with a flow rate of $300 \mathrm{gpm}$ at 15- and 25acre spacing, and $1000 \mathrm{gpm}$ with 25-acre spacing. By using ratios of costs, estimates were obtained for the 1000-gpm, 15-acre combination. It was assumed that, for systems with more than 16 wells, the unit costs would be given by the results for the 16 -well field. Costs were not included for a separate ATES cooling tower because it is assumed that the excess cooling tower capacit/ of the plant could be used in winter. Land costs were not included because it is assumed that the utility owns the land close to the plant. The cost. range for the wells is obtained from a water well cost survey (National Water Well Association 1979) for wells producing $1000 \mathrm{gpm}$ or more with depths from 65 to $2000 \mathrm{ft}$. The cost range for the heat exchanger is taken from Meyer and Hauz (1980) with the lower cost corresponding to carbon steel construction and the higher cost for stainless steel. Heat exchanger unit cost includes installation, fittings, and valves. 
IABLE 3.2. Cost Summary(a), 1987 Dollars

Fixed capital costs

Literature search

Reconnaissance

Aquifer characterization

Pump test

Tracer test

Anisotropy test

Geophysical log

Microbiology/geochemistry

Exploration drilling

36,600

1,200

3,700

6,000

18,400

12,300

49,000

Variable capital costs

Environmental impact statement

Equipment

Well and pump $(1000 \mathrm{gpm})^{(b)}$

Heat exchanger $(c)$

Piping

Transmission

(from wells to manifold) 2 wells $367,500 /$ well

4 wells $240,960 /$ well

16 wells $96,530 /$ well

Manifold (from field to day tank) 2 wells $92,400 /$ well

4 wells $95,200 /$ well

16 wells $139,000 /$ well

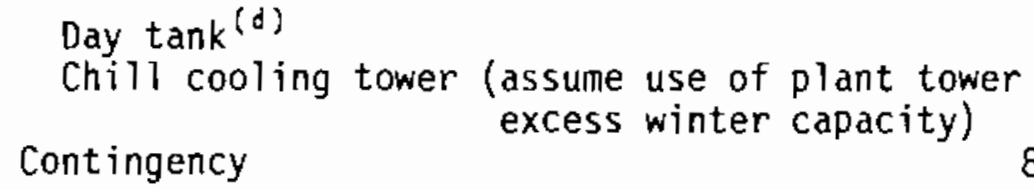

Chill cooling tower (assume use of plant tower

Contingency

$24 / \mathrm{m}^{3}$

$0.0 /$ well

$8 \%$ of equipment

Operation and maintenance costs, such as

maintenance and supplies, well abandonment

general and administrative (G\&A), repair and

replacement, (function of number of wells):

2 wells $63,200 /$ well-yr

4 wells $54,086 /$ well-yr

16 wells $37,100 /$ well-yr

Electricity

Recovery and injection pumping

$0.041 / \mathrm{kW}-\mathrm{h}$

Chilled water production source and injection

Chilled water production cooling tower fan power

(a) All costs from Brown (1983) except as noted.

(b) National Water Well Association (1979)

(c) Meyer and Hauz (1980)

(d) Petri, Ong, and 0lscewski (1984) 


\section{$3.4 .2 \underline{0} \& M$ Costs}

Operation and maintenance costs also depended on the number of wells and were taken from Brown (1983). Electricity costs are separate from other 0\&M cost components in Table 3.2. This was done to allow for different well depth than was used by Brown (1983). The pumping power is determined from

$$
\text { POW }=\left[H E A D\left(\dot{m}_{\mathrm{ad}}\right) T I M E / P E F F\right] \times 2 \quad[\mathrm{~kW}]
$$

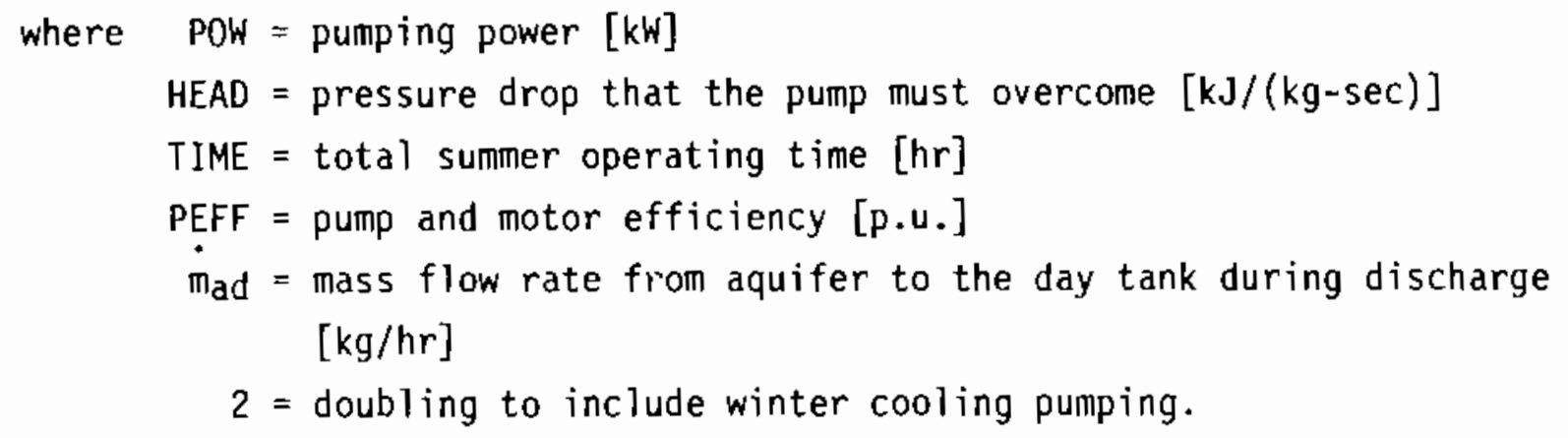

Fan power associated with winter cooling tower operation to chill the aquifer water was estimated by assuming that $1 / 3$ of the cooling tower capacity would be available for winter chilling. Installed fan power for the Middletown plant was estimated by scaling the installed fan power for a typical 1100-MW nuclear power plant. This resulted in an estimated fan power of $2106 \mathrm{~kW}$. Multiplying this value by the number of hours of winter chilling gave the total energy consumption.

The sum of pumping and fan energy consumption was multiplied by the unit electricity cost to obtain the annual electricity cost for the ATES system.

\subsubsection{Levelized Energy Costs and Unit Capital Costs}

Two costs are obtained: levelized energy cost and unit capital cost. Levelized energy cost is given by Equation (3.23).

$$
L E C=\frac{C C \times F C R+(08 M+E L E C)}{\left(P_{\text {EATES }} \times \text { TIME }\right)-E} \quad[\$ / M W h]
$$

where $\quad L E C=$ levelized energy cost $[\$ / M W h]$

$$
C C=\text { capital cost }[\$]
$$




$$
\begin{aligned}
& F C R=\text { fixed charge rate (assumed to be } 0.18 \text { ) } \\
& \text { O\&M = annual operations and maintenance cost [\$/year] } \\
& E L E C=\text { cost of electricity for pumping and for fan power of the } \\
& \text { cooling tower during winter cooling [\$/year] } \\
& E=\text { electrical energy for operation without ATES Equation [MWh] } \\
& P_{\text {EATES }}=\text { electric power output with ATES for selected condenser pressure } \\
& \text { [MW] (PE from Table 3.1). }
\end{aligned}
$$

Unit capital cost is given by Equation (3.24)

$$
U C C=\frac{C C}{\left(P_{\text {EATES }}-P_{\text {EP }}\right) \times 1000}
$$

where UCC is the unit capital cost and $P_{E P}$ is the electric power output of the plant without ATES at maximum wet-bulb temperature $\left[P_{E S}\right.$ is either taken from Equation (3.11) or is given by $P_{E}$ in Table 3.1]. 



\subsection{SELECTION OF CASES}

The study was limited to retrofit application to power plants with evaporative cooling towers. Within the scope, the major variables are location, cooling tower effectiveness, circulating water temperature range, desired condenser conditions, number of hours of desired operation, aquifer recovery temperature, and component unit costs. The location determines the meteorology and characteristics of the aquifer. Aquifer characteristics affect the cost of drilling wells and the well spacing, but for this study, it was assumed that well spacing and well costs were similar for the two locations considered.

It was decided to perform cost calculations to obtain the optimum cost system at various combinations of the following variables of range and effectiveness:

- two locations: Middletown, U.S.A. (Washington, D.C.) and Jacksonville, Florida

- two condenser pressures: 2.5 and $3.5 \mathrm{in} . \mathrm{Hg}$

- two operational scenarios

- two capital cost variations [high and low cost wells and heat exchanger $(H x)]$

- two aquifer recovery temperatures.

Middletown and Jacksonville were selected to give a range of environmental conditions. Middletown, U.S.A., is an average U.S. site with relatively mild summer climatic conditions for heat rejection. Jacksonville, Florida, is a site with extreme conditions for summer heat rejection. Seven cases are summarized in Table 4.1. In practice, cooling tower effectiveness ranges from 0.4 to 0.6 and circulating water temperature ranges have been observed as low as $8^{\circ} \mathrm{C}$ and as high as $16^{\circ} \mathrm{C}$. Selecting 3 effectiveness values $(0.4$, 0.5 , and 0.6$)$, a long with 5 values of range $\left(8,10,12,14\right.$, and $16^{\circ} \mathrm{C}$ ), provides 15 combinations for each of the 7 cases. Some of the combinations would not benefit from an ATES system because there are no hours during the year that 
IABLE 4.1. Variations Studied

\begin{tabular}{|c|c|c|c|c|c|c|c|}
\hline & $\begin{array}{l}\text { Base } \\
\text { Case }\end{array}$ & $\begin{array}{l}\text { Case } \\
2 \\
\end{array}$ & $\begin{array}{c}\text { Case } \\
-3 \\
\end{array}$ & $\begin{array}{l}\text { Case } \\
-5 \\
\end{array}$ & $\begin{array}{l}\text { Case } \\
6 \\
\end{array}$ & $\begin{array}{c}\text { Case } \\
7 \\
\end{array}$ & $\begin{array}{c}\text { Case } \\
8 \\
\end{array}$ \\
\hline \multicolumn{8}{|l|}{ Location } \\
\hline Middletown & $x$ & $x$ & $x$ & & $x$ & & $x$ \\
\hline Jacksonville & & & & $x$ & & $x$ & \\
\hline \multicolumn{8}{|l|}{$\begin{array}{l}\text { Aquifer recovery } \\
\text { temperature }\end{array}$} \\
\hline $6.67^{\circ} \mathrm{C}\left(44^{\circ} \mathrm{F}\right)$ & & & & $x$ & & $x$ & $x$ \\
\hline $4.5^{\circ} \mathrm{C}\left(40^{\circ} \mathrm{F}\right)$ & $x$ & $x$ & $x$ & & $x$ & & \\
\hline \multicolumn{8}{|l|}{ Condenser pressure } \\
\hline $3.5 \mathrm{in.} \mathrm{Hg}$ & $x$ & $x$ & $x$ & $x$ & & & $x$ \\
\hline 2.5 in. $\mathrm{Hg}$ & & & & & $x$ & $x$ & \\
\hline \multicolumn{8}{|l|}{ Operation } \\
\hline $4 \mathrm{hr} /$ day, 135 days & $x$ & & $x$ & $x$ & $x$ & $x$ & $x$ \\
\hline $6 \mathrm{hr} /$ day, 180 days & & $x$ & & & & & \\
\hline \multicolumn{8}{|l|}{ Capital costs } \\
\hline $\begin{array}{l}\text { Lowest cost } \\
\text { wells and } \mathrm{Hx}\end{array}$ & & & $x$ & $x$ & & $x$ & \\
\hline $\begin{array}{l}\text { Highest cost } \\
\text { wells and } H x\end{array}$ & $x$ & $x$ & & & $x$ & & $\mathrm{x}$ \\
\hline
\end{tabular}

cause the condenser pressure to exceed its design conditions. These combinations are indicated by a zero in Tables 4.2 and 4.3 . Table 4.2 reports results for a condenser pressure of $3.5 \mathrm{in}$. $\mathrm{Hg}$, and Table 4.3 reports results for $2.5 \mathrm{in.} \mathrm{Hg}$. Thus, optimized costs are obtained only for the non-zero combinations. 
TABLE 4.2. Hours Above $3.5 \mathrm{in.} \mathrm{Hg}$ in Middletown

\begin{tabular}{crrrrr} 
& \multicolumn{6}{c}{ Range, ${ }^{\circ} \mathrm{C}$} \\
\cline { 2 - 6 } Effectiveness & \multicolumn{8}{c}{} & $\underline{10}$ & $\frac{12}{288}$ & $\frac{12}{1597}$ & $\frac{14}{3358}$ & $\frac{16}{4673}$ \\
\hline 0.4 & 0 & 0 & 211 & 1138 & 2277 \\
0.5 & 0 & 0 & 0 & 133 & 797 \\
0.6 & & & & &
\end{tabular}

TABLE 4.3. Hours Above $2.5 \mathrm{in}$. Hg in Middletown

\begin{tabular}{crrrrr} 
& \multicolumn{6}{c}{ Range, ${ }^{\circ} \mathrm{C}$} \\
\cline { 2 - 7 } Effectiveness & $\frac{8}{797}$ & $\frac{10}{2279}$ & $\frac{12}{4014}$ & $\frac{14}{5332}$ & $\frac{16}{7122}$ \\
\hline 0.4 & 48 & 797 & 1865 & 3358 & 4336 \\
0.5 & 0 & 133 & 797 & 1865 & 3011 \\
0.6 & & & &
\end{tabular}





\subsection{RESULTS}

Results are reported in levelized energy costs (mills/kWh) and unit capital costs $(\$ / \mathrm{kWe})$. However, these figures-of-merit are based on gross energy and gross power, respectively. Gross energy and power do not include the impact of parasitic power consumption, which results in the costs being lower than if net energy and power were used. On the other hand, cooling tower fans may not be needed for winter chill; without the fans, levelized costs would be lower because cooling tower fan consumption is $50 \%$ of annual cost and about $20 \%$ of levelized energy costs. Nevertheless, useful comparisons can be made between successive cases because consistent procedures were used for all cases.

Results for cases 2 through 8 are compared against the base case in Figures 5.1 to 5.12. All of the curves have the same general shape: decreasing cost with increasing range and/or decreasing effectiveness. A plateau appears for cases of lower condenser pressure.

Figures 5.1 and 5.2 show that costs are slightly higher for a $6 \mathrm{hr} /$ day, 180-day operation (case 2) than for a $4 \mathrm{hr} /$ day, 135-day operation (base case). The reason is that for the $6 \mathrm{hr} /$ day case, more wells, larger heat exchanger, larger day tank, and more pumping are required to provide the required cooling. If cooling for $4 \mathrm{hr} /$ day was required for more than 135 days, the levelized energy cost would be reduced.

The base case is compared to higher aquifer recovery temperature (case 8 ) in Figures 5.3 and 5.4 . For a $2^{\circ} \mathrm{C}$ aquifer recovery temperature increase, levelized and capital costs rise from 20 to $100 \$ /$ MWh and from 10 to $50 \$ / \mathrm{kWe}$. This demonstrates the importance of maintaining the aquifer at as low a temperature as possible.

The base case is compared to reduced unit costs for wells and heat exchanger (case 3) in Figures 5.5 and 5.6. For an estimated well cost of $1 / 3$ the base-case cost and heat exchanger cost of $1 / 2$ of the base-case cost, system costs are reduced by about $30 \%$. 
Costs drop dramatically for case 5 (Figures 5.7 and 5.8), which simulates a plant located at Jacksonville, Florida, with low-cost wells and heat exchanger. The lower costs are caused by the many hours of high wet-bulb temperature. (See Appendix B.) The extreme sumner high temperatures more than compensated for the warmer winter aquifer temperature $\left(6.67^{\circ} \mathrm{C}\right)$, compared to Middletown $\left(4.5^{\circ} \mathrm{C}\right)$.

In Figures 5.1 through 5.8, ATES is beneficial for condenser ranges from $10^{\circ} \mathrm{C}$ or $11^{\circ} \mathrm{C}$ to $16^{\circ} \mathrm{C}$. None of the variations so far show reasonable costs for the condenser ranges between $8{ }^{\circ} \mathrm{C}$ and $10^{\circ} \mathrm{C}$ because the condenser pressure was held at $3.5 \mathrm{in.} \mathrm{Hg}$ for these cases.

The condenser pressure was reduced to $2.5 \mathrm{in.} \mathrm{Hg}$ in Figures 5.9 through 5.12. In 5.9 and 5.10 (case 6), it can be seen that ATES costs, though high, are orders of magnitude less than for the 3.5-in. $-\mathrm{Hg}$ condenser pressure in the $8^{\circ} \mathrm{C}$ to $10^{\circ} \mathrm{C}$ ranges. The lines cross, however, making the 2.5-in.-Hg ATES system more expensive for large ranges.

Picking parameters to give the lowest possible costs for ranges $8^{\circ} \mathrm{C}$ to $10^{\circ} \mathrm{C}$ resulted in Figures 5.11 and 5.12 (case 7). Again, the costs are high.

The horizontal plateaus on Figures 5.10 through 5.12 are not fully understood. It may be a real effect or a combination of coarse-binned temperature data and the use of discrete points in optimization. It is possible that the "knee" (right side) of the plateau is not the minimum for that point. We did observe some cases of two minima and picked the smaller. In the right-side plateau points, it may be that the optimization window was too small to catch the second minima. This would require further work beyond the scope of this study.

Thus, the lowest-cost ATES systems for augmenting evaporative cooling towers will be in the southern U.S. (Jacksonville, Florida), operating $4 \mathrm{hr} /$ diy for 135 days. For plants with circulating water temperature ranges from $8^{\circ} \mathrm{C}$ to $10^{\circ} \mathrm{C}$, the levelized cost will be from 600 to $800 \mathrm{mills} / \mathrm{kWh}$ and capital costs from 500 to $1300 \$ / \mathrm{kWe}$, assuming condensers are cooled to $2.5 \mathrm{in}$. Hg. For ranges higher than $10^{\circ} \mathrm{C}, 3.5-\mathrm{in} .-\mathrm{Hg}$ condenser pressure produces the lowest costs of 50 to $800 \mathrm{mills} / \mathrm{kWh}$ and 100 to $1100 \$ / \mathrm{kWe}$. 


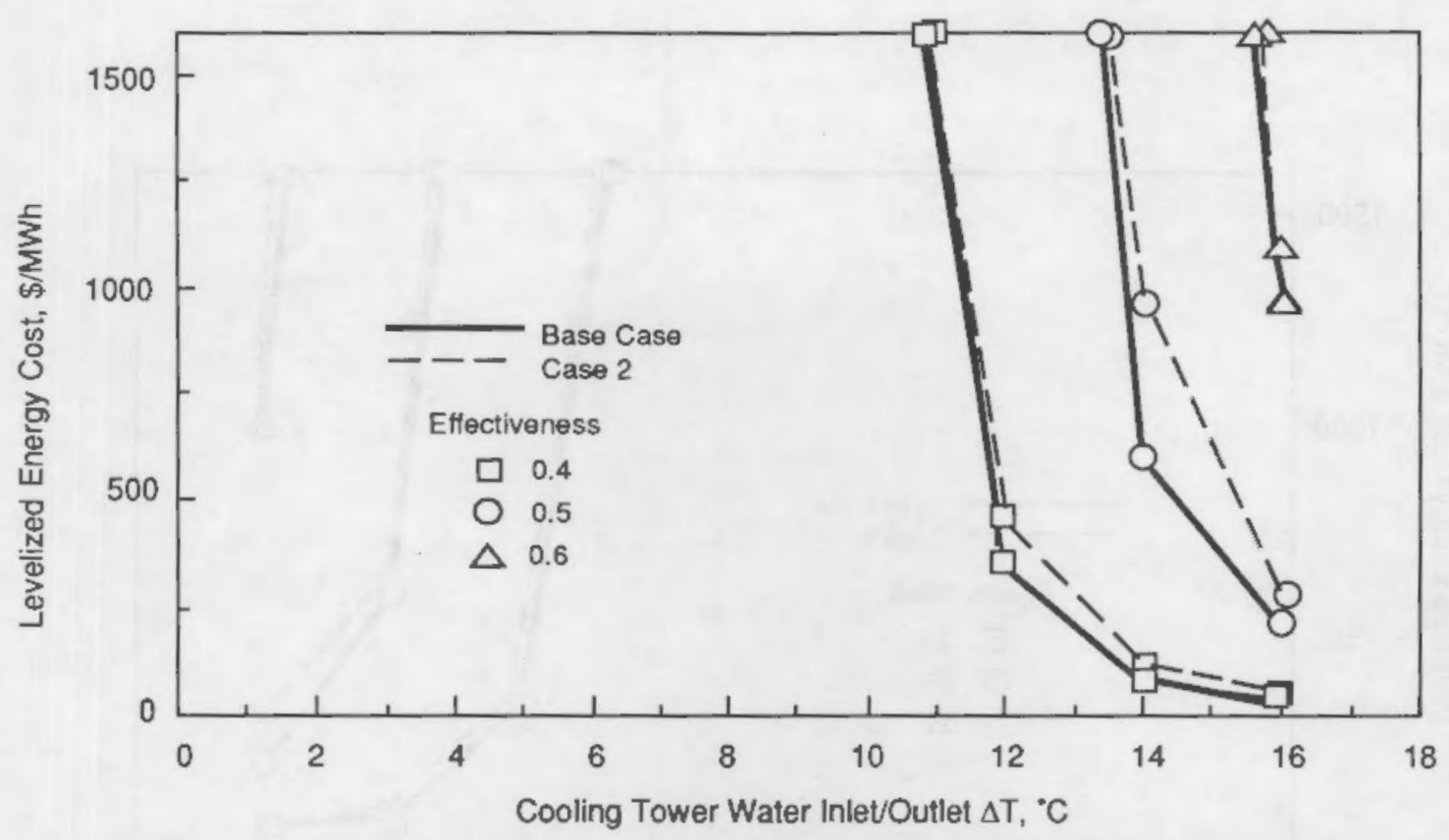

FIGURE 5.1. Comparison of Levelized Energy Cost of Base Case and Case 2 (6 hr/day, 180-day operation)

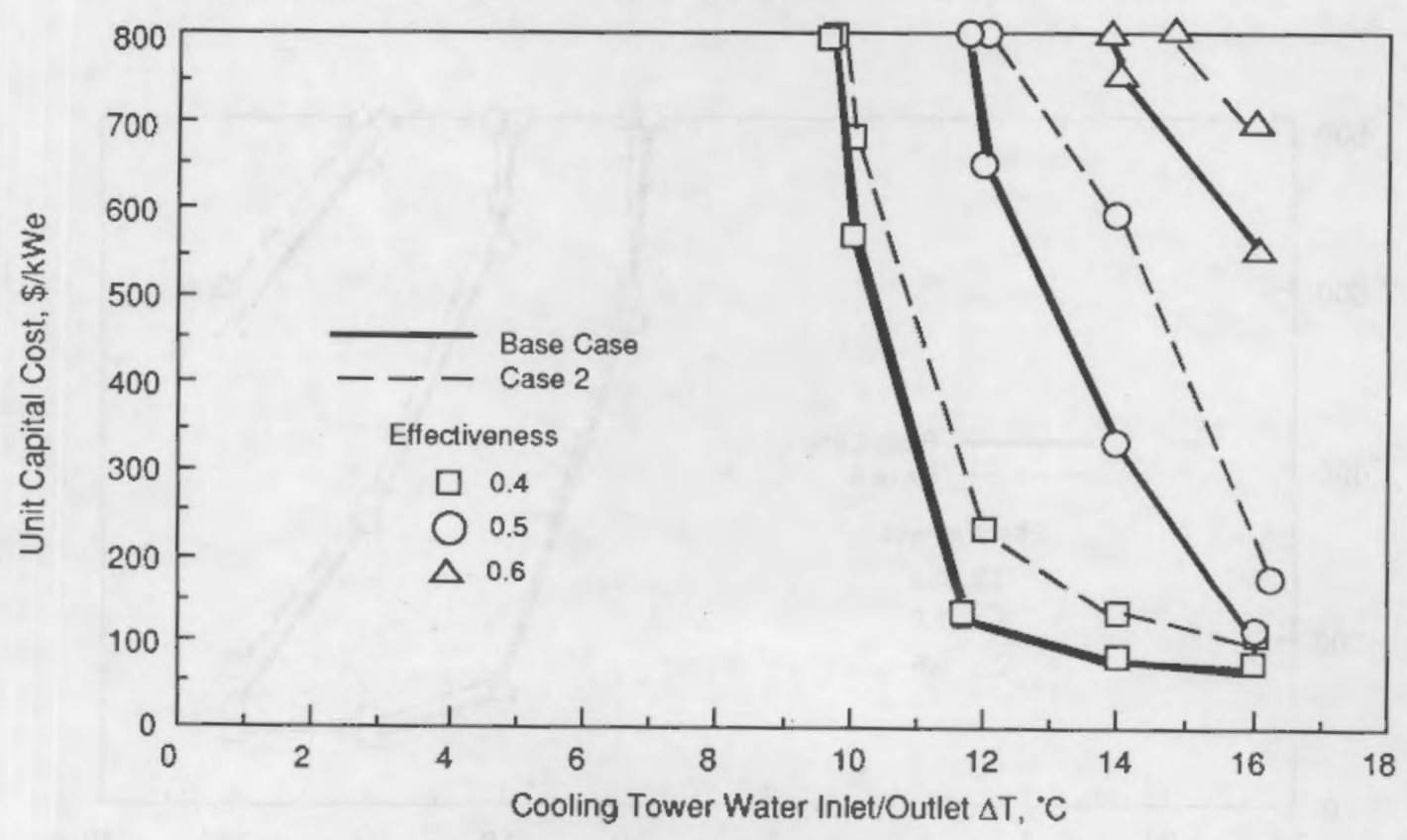

FIGURE 5.2. Comparison of Unit Capital Cost of Base Case and Case 2 (6 hr/day, 180-day operation)

CONCLUSION: Extended ATES cooling system operation period slightly increases cost. 


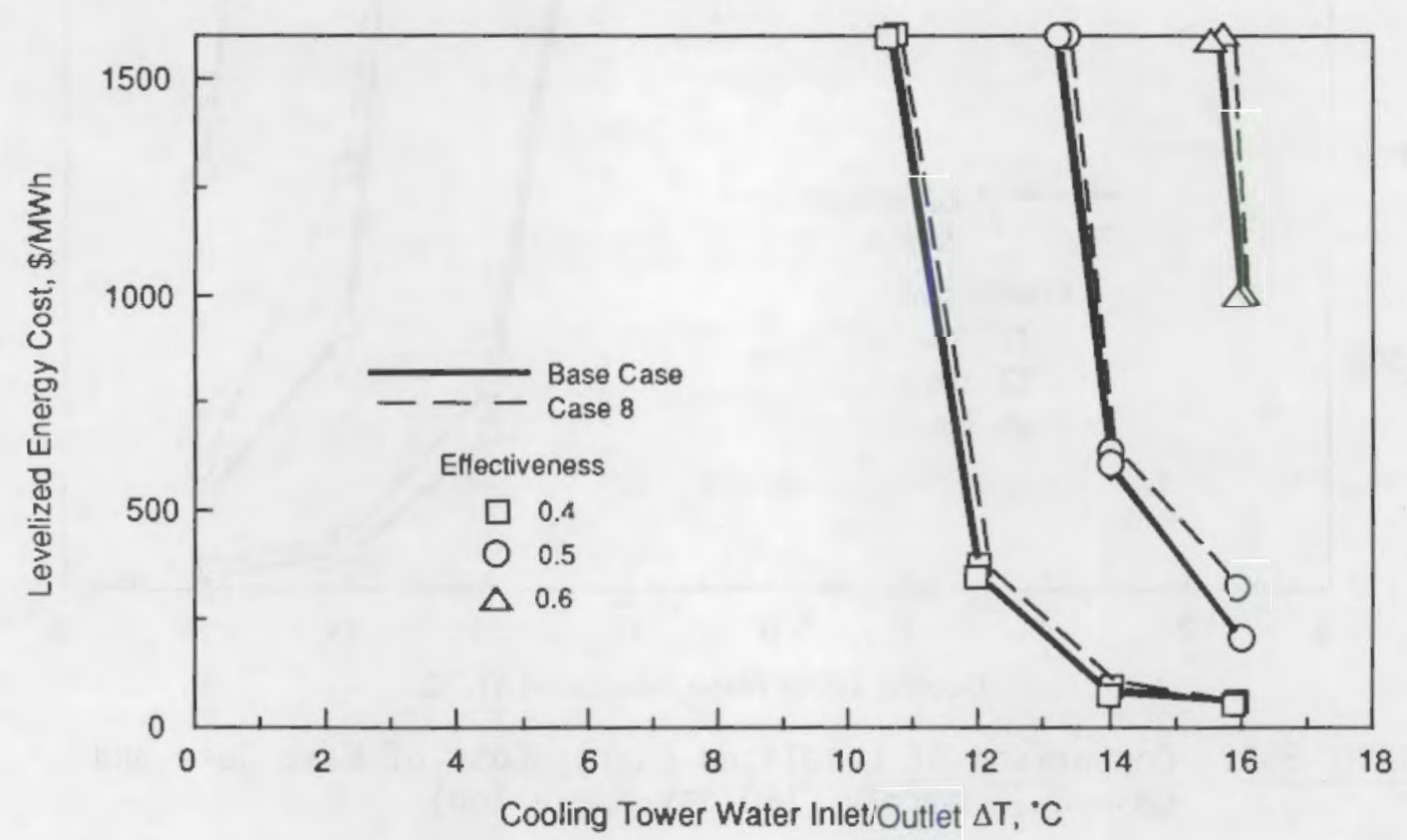

FIGURE 5.3. Comparison of Levelized Energy Cost of Base Case and Case 8 [Aquifer recovery temperature of $6.67^{\circ} \mathrm{C}\left(44^{\circ} \mathrm{F}\right)$ ]

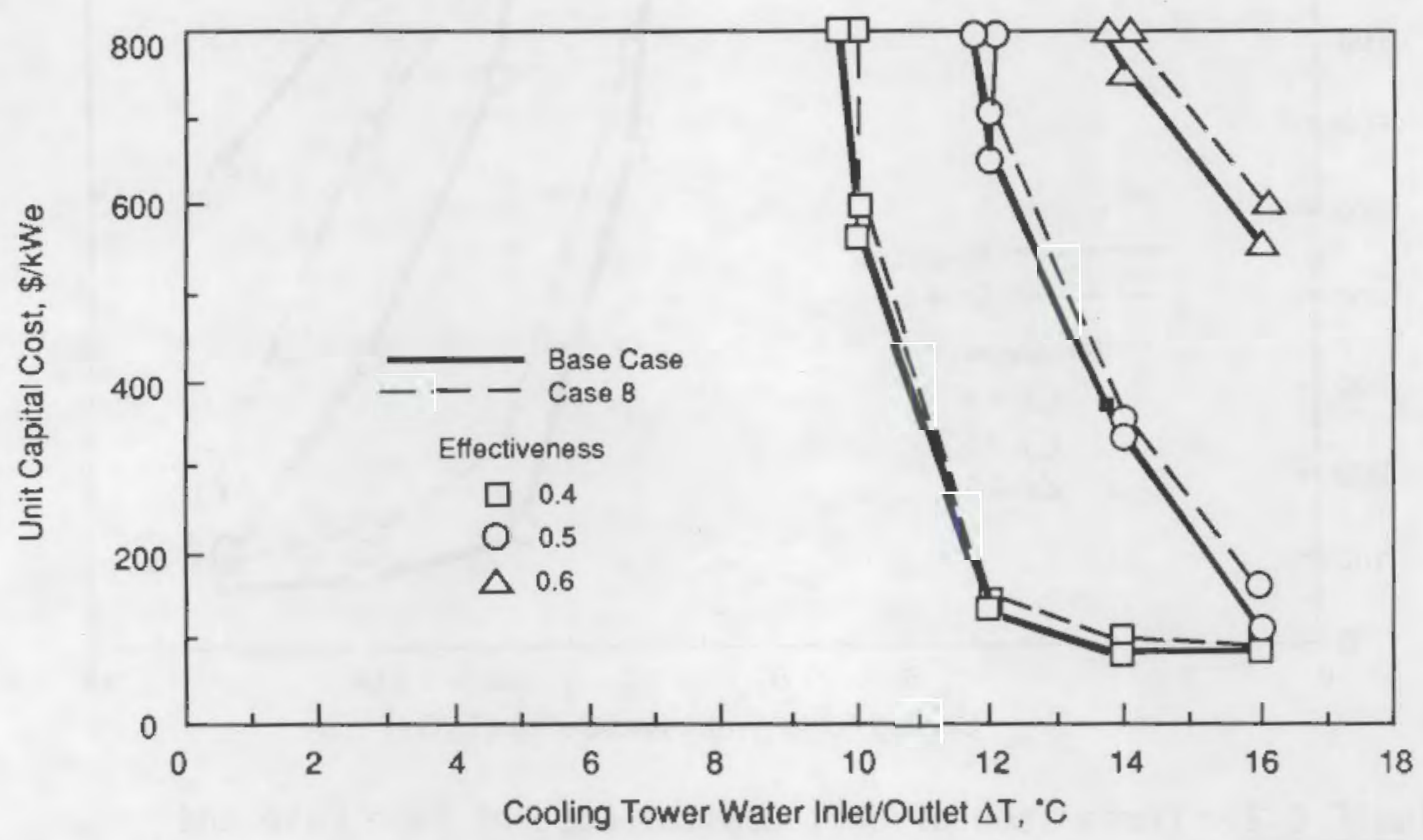

FIGURE 5.4. Comparison of Unit Capital Cost of Base Case and Case 8 [Aquifer recovery temperature of $6.67^{\circ} \mathrm{C}\left(44^{\circ} \mathrm{F}\right)$ ]

CONCLUSION: A $2^{\circ} \mathrm{C}$ increase in the temperature of cooling water in the aquifer slightly increases cost. 


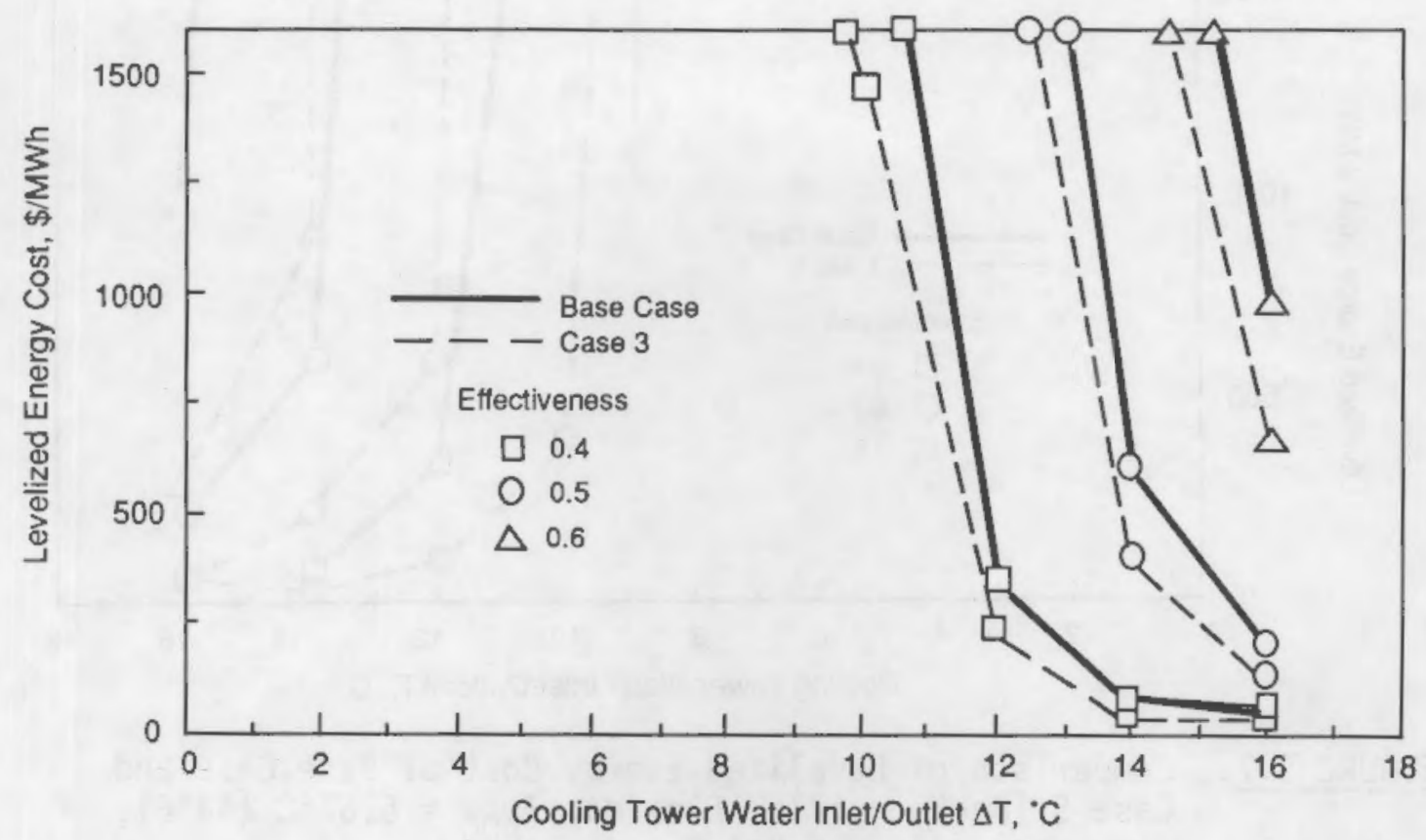

FIGURE 5.5. Comparison of Levelized Energy Cost of Base Case and Case 3 (Low cost wells and $\mathrm{Hx}$ )

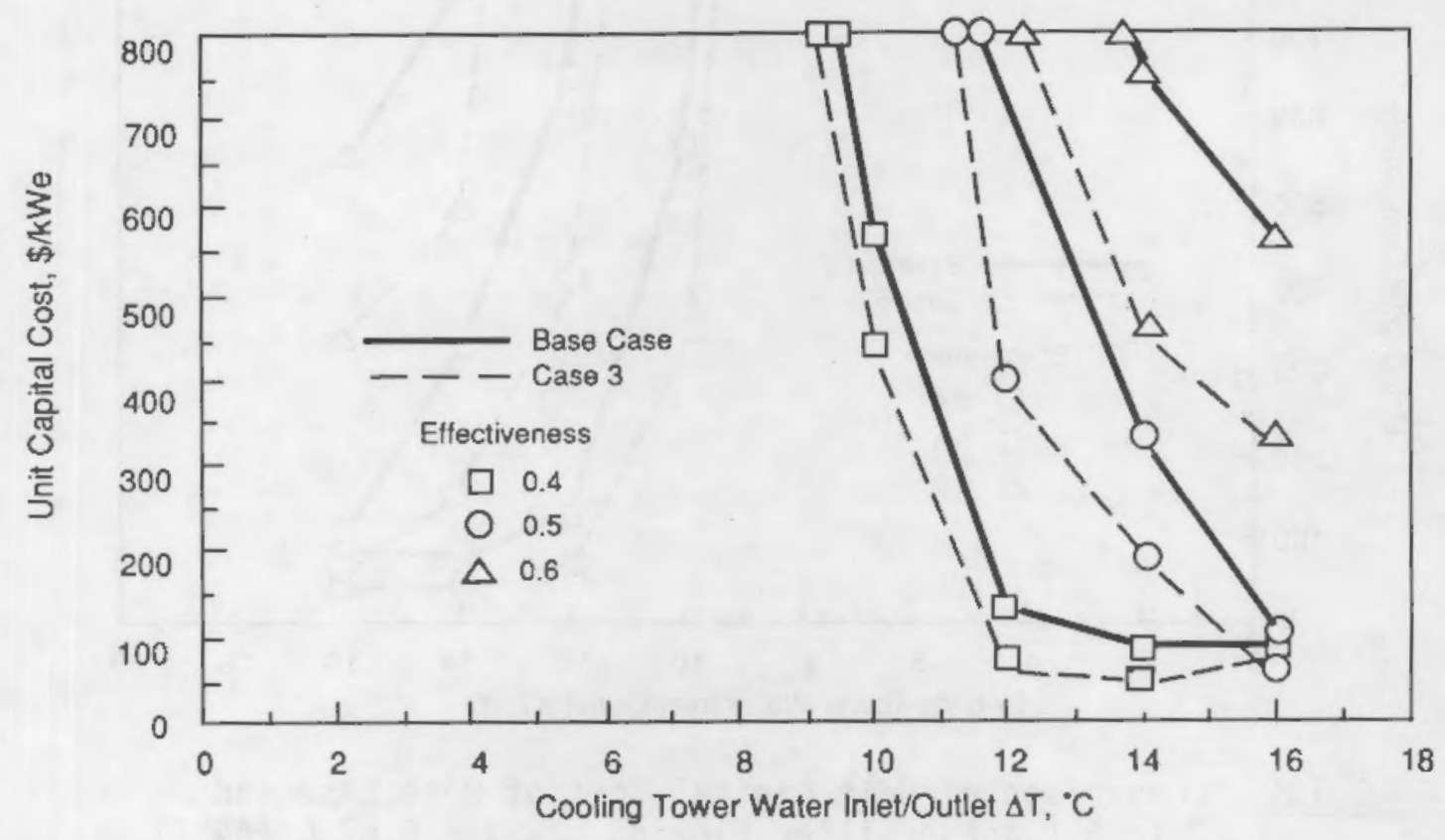

FIGURE 5.6. Comparison of Unit Capital Cost of Base Case and Case 3 (Low cost wells and $\mathrm{Hx}$ )

CONCLUSION: Low cost heat exchangers and wells substantially decrease cost. 


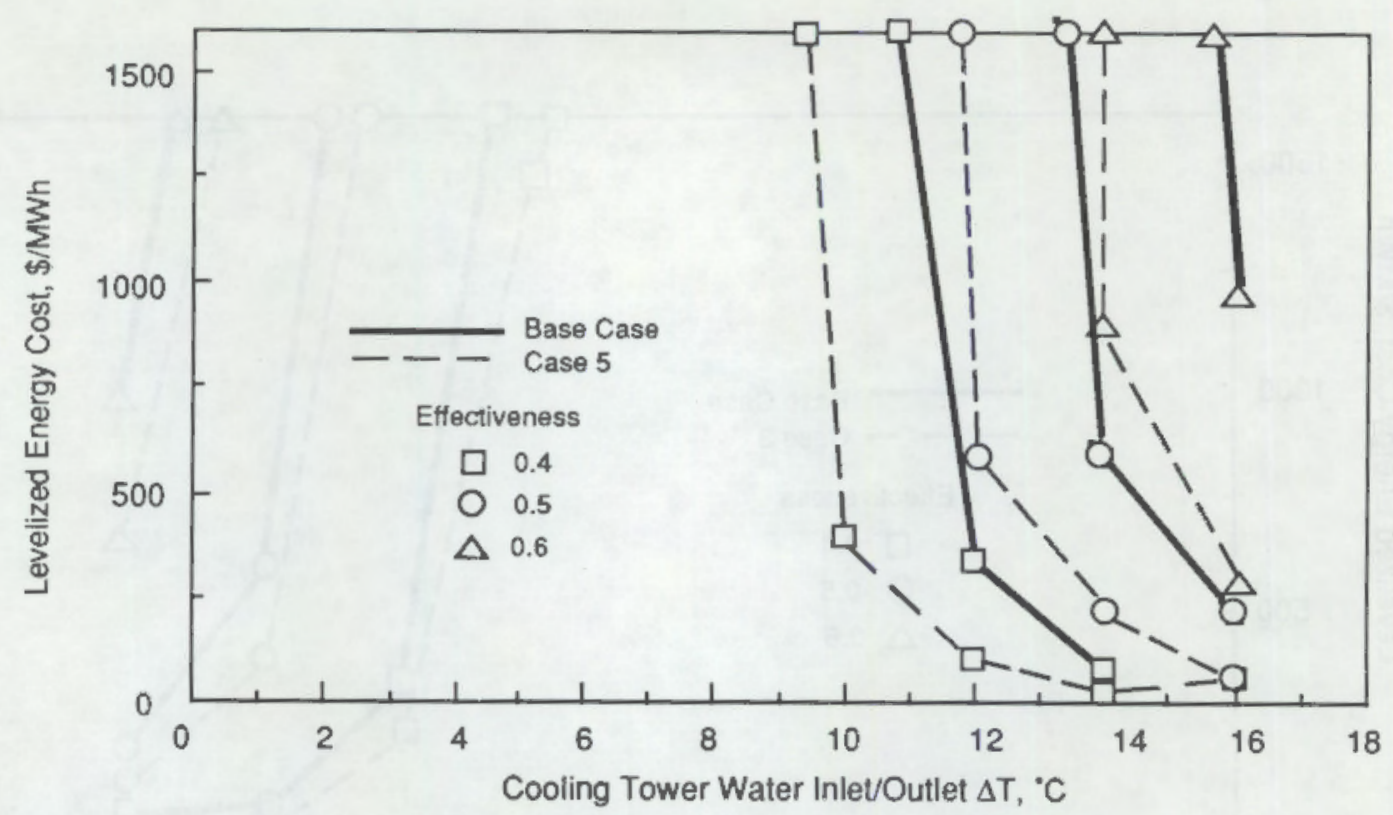

FIGURE 5.7. Comparison of Levelized Energy Cost of Base Case and Case 5 [Jacksonville, Florida, $\mathrm{T}_{A Q O}=6.67^{\circ} \mathrm{C}\left(44^{\circ} \mathrm{F}\right)$, low cost wells and $\mathrm{Hx}$ ]

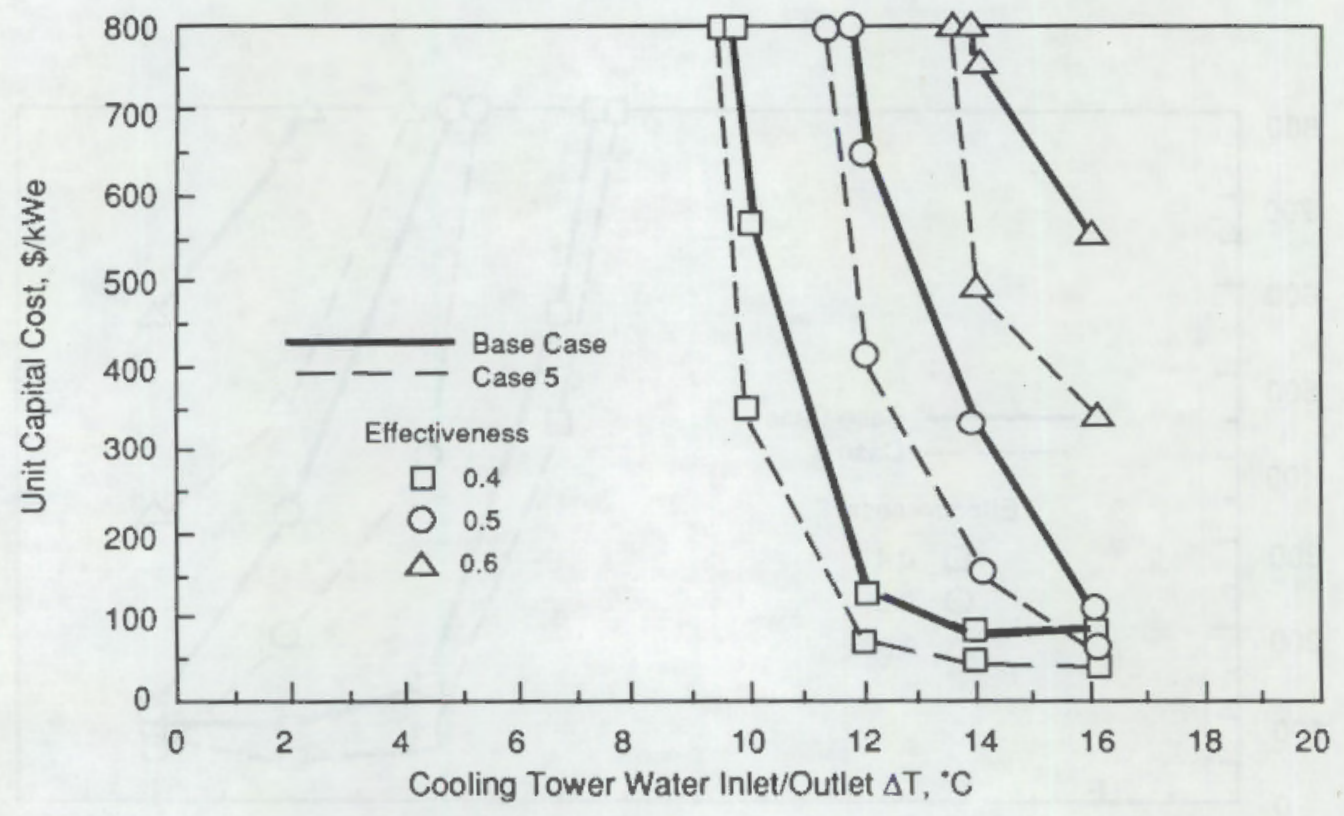

FIGURE 5.8. Comparison of Unit Capital Cost of Base Case and Case 5 [Jacksonville, Florida, $T_{A Q O}=6.67^{\circ} \mathrm{C}\left(44^{\circ} \mathrm{F}\right)$,
low cost wells

CONCLUSION: The costs for a plant installed at Jacksonville, Florida are substantially below the costs associated with a plant located in New England. 


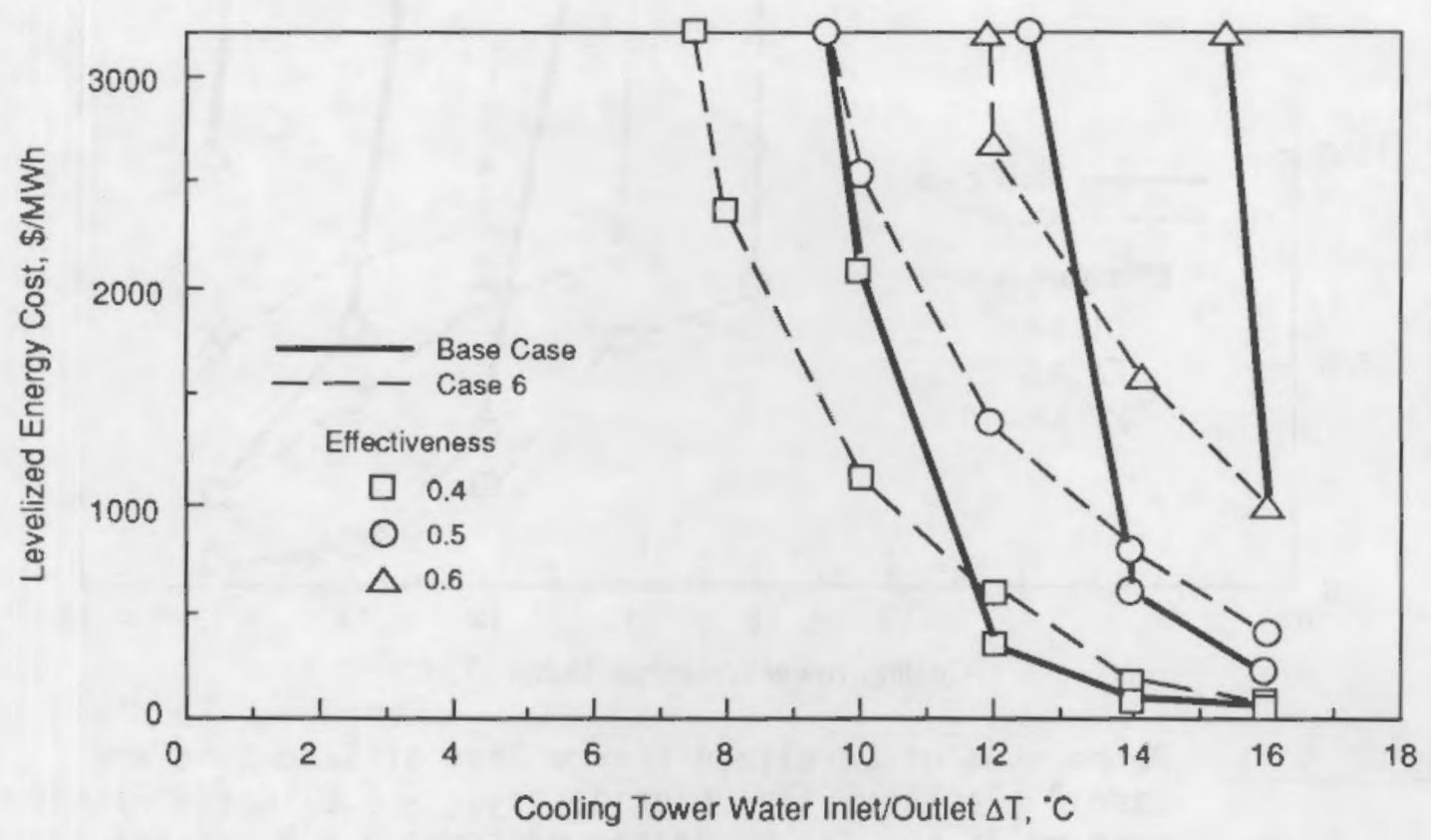

FIGURE 5.9. Comparison of Levelized Energy Cost of Base Case and Case 6 (condenser pressure at $2.5 \mathrm{in}$. $\mathrm{Hg}$ )

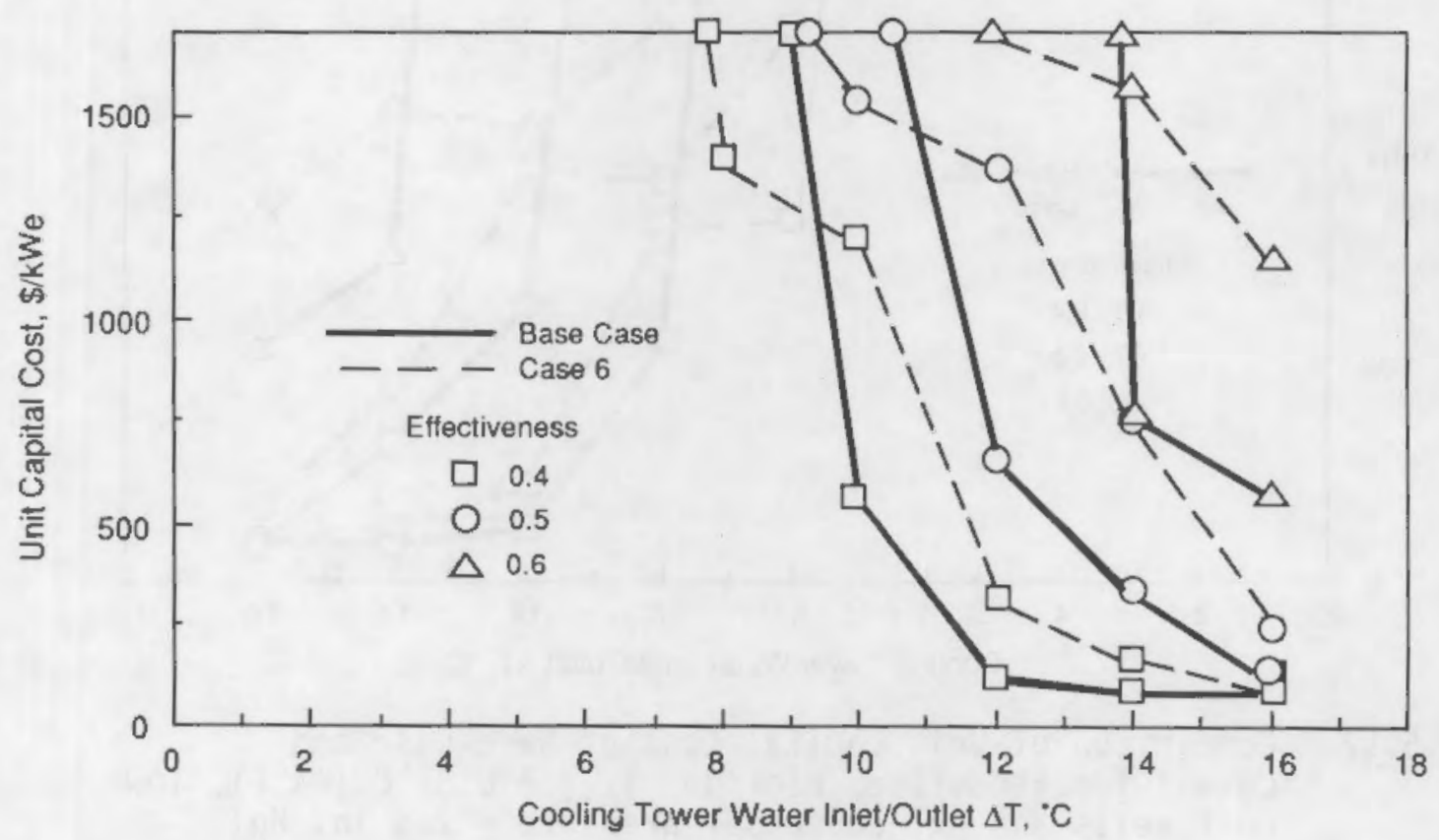

FIGURE 5.10. Comparison of Unit Capital cost of Base Case and Case 6 (condenser pressure at $2.5 \mathrm{in}$. $\mathrm{Hg}$ )

CONCLUSION: Decreasing target turbine backpressure to $2.5 \mathrm{in}$. Hg substantially increases the cost of the system. 


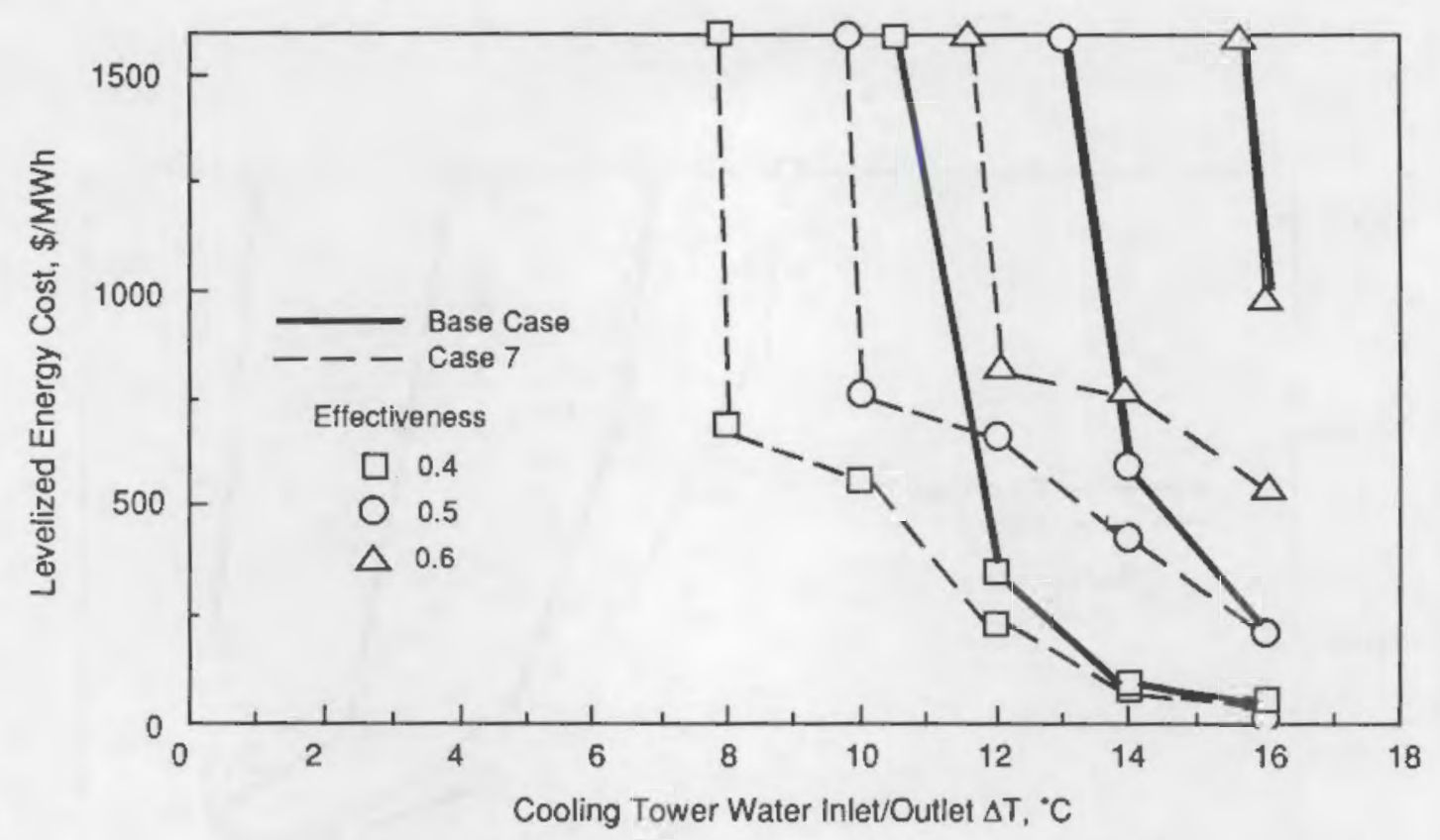

FIGURE 5.11. Comparison of Levelized Energy Cost of Base Case and Case 7 [Jacksonville, Florida, $\mathrm{T}_{\mathrm{Aq} O}=6.67^{\circ} \mathrm{C}\left(44^{\circ} \mathrm{F}\right)$, low cost wells and $\mathrm{Hx}$, condenser pressure $=2.5 \mathrm{in}$. $\mathrm{Hg}]$

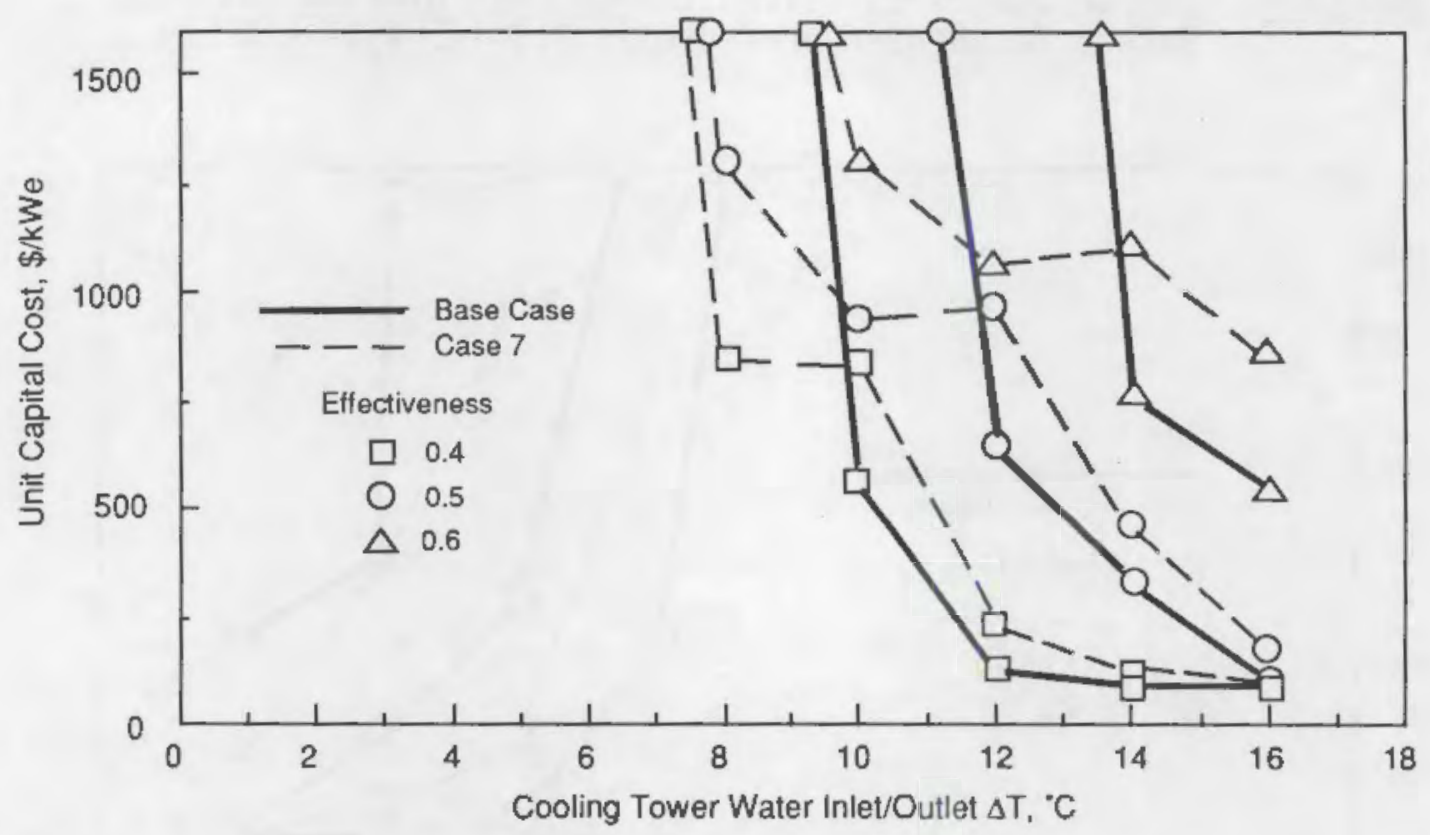

FIGURE 5.12. Comparison of Unit Capital Cost of Base Case and Case 7 [Jacksonville, Florida, $T_{A Q D}=6.67^{\circ} \mathrm{C}\left(44^{\circ} \mathrm{F}\right)$, low cost wells and $\mathrm{Hx}$, condenser pressure $=2.5 \mathrm{in}$. $\mathrm{Hg}]$

CONCLUSION: Using a combination of low cost assumptions, the ATES system is not competitive when cooling tower range is less than $10^{\circ} \mathrm{C}$. 


\subsection{CONCLUSIONS}

The results of this study show the economic attractiveness of the peak cooling of power plants using ATES as a function of plant cooling system performance characteristics and ambient conditions. Based on these results, a number of conclusions can be drawn including:

- Cooling System Characteristics - For a cooling system range between 10 and $16^{\circ} \mathrm{C}$ and a cooling tower effectiveness less than 0.5 , the ATES system can be competitive with other sources of peak power. In these situations, the levelized cost of power can be as low as $50 \mathrm{mills} / \mathrm{kWh}$ for a capacity factor of between 0.06 and 0.12 . For very low capacity factors, any source of electric power will be expensive. As cooling system range or cooling tower effectiveness increases, the ATES system rapidly becomes uneconomical. This suggests that there may be a market niche where the ATES system for power plant peak cooling may be attractive. Applications would consist of power plants with undersized cooling systems or cooling towers that do not meet design performance requirements.

- Ambient Conditions - The ATES system is more attractive in hot, humid climates where the perfomance penalty associated with high ambient temperature is largest.

- Other Applications - The study only considered retrofit application with evaporative cooling systems. In new construction, the ATES system would allow the intentional undersizing of the cooling towers because peak cooling loads would be met with the ATES system. Dry cooling applications are attractive because of the large performance penalty associated with operating a completely dry cooling system at high ambient temperatures. 



\subsection{REFERENCES}

Brown, 0. R. 1983. Aquifer Thermal Energy Storage Costs with a Seasonal Chill Source. PNL-4587, Pacific Northwest Laboratory, Richland, Washington.

Drost, M. K., and B. M. Johnson. 1980. Cost Analys is of an Ammonia Ory Cooling System with a Chicago Bridge and Iron Peak Shaving System. PNL-3272, Pacific Northwest Laboratory, Richland, Washington.

Kays, W. M., and A. L. London. 1964. Compact Heat Exchangers. McGraw-Hill, New York, New York.

Meyer, C. F., and W. Hauz. 1980. Guidelines for Conceptual Design and Evaluation of Aquifer Themal Energy Storage. PNL-3581, Pacific Northwest Laboratory, Richland, Washington.

National Water Well Association. 1979. Water Well Drilling Cost Survey. Work performed under order no. $86 \mathrm{X}-42541 \mathrm{~V}$ for 0ak Ridge National Laboratory, Oak Ridge, Tennessee by National Water Well Association, Worthington, Ohio.

Pacific Northwest Laboratory. 1984. Weather Data for Simplified Energy Calculation Methods, Vol. 1 - Eastern United States TRY Data. PNL-5143, Volume 1, Richland, Washington.

Petri, R. J., E. T. Ong, and M. 01scewski. 1984. "High Temperature Composite Themal Storage Systems." In Proceedings of 19th Intersociety Energy Conversion Engineering Conference, Vol. 2, pp. 1097-1102. American Nuclear Society, Hinsdale, Illinois.

U.S. Nuclear Regulatory Commission. 1987. Licensed Operating Reactors. Status Sumnary Report, Data as of June 7, 1987. NUREG-0020, Vo1. 11, No. 7 , Office of Information Services Management monthly publication, Washington $0 . C$.

Welty, J. R., C. E. Wicks, and R. E. Wilson. 1976. Fundamentals of Momentum, Heat and Mass Transfer. John Wiley and Sons, New York, New York. 

APPENDIX A

POWER PLANT CAPACITIES FROM LICENSEO OPERATING REACTORS, NUREG-0020 
APPENDIX A

POWER PLANT CAPACITIES FROM LICENSEO OPERATING REACTORS, NUREG-0020

List of Power Plants with Their Maximum Reliable Capacity and Type of Cooling

\begin{tabular}{|c|c|c|c|c|}
\hline & Rates Mwe & $\begin{array}{l}\text { Maximum } \\
\text { ReTiable } \\
\text { Capacity }\end{array}$ & Delta & Type of Cooling \\
\hline ANO-1 & 850 & 836 & 14 & Reservoir, Ark R \\
\hline ANO -2 & 912 & 858 & 54 & Tower (natural) \\
\hline Beaver Valley-1 & 835 & 810 & 25 & Towers (natural) \\
\hline Browns Ferry 1 & 1065 & 1065 & 0 & Combined cycle \\
\hline Browns Ferry 2 & 1065 & 1065 & 0 & Combined cycle \\
\hline Browns Ferry 3 & 1065 & 1065 & 0 & Combined cycle \\
\hline Brunswick 1 & 821 & 790 & 31 & At 10 outfall \\
\hline Brunswick 2 & 821 & 790 & 31 & Atl 0 outfall \\
\hline Byron & 1120 & 1129 & -9 & Towers (natural) \\
\hline Callaway 1 & 1171 & 1120 & 51 & Tower (natural) \\
\hline Calvert Cliffs-1 & 845 & 825 & 20 & Chesapeake Bay \\
\hline Calvert Cliffs-2 & 845 & 825 & 20 & Chesapeake Bay \\
\hline Catawba-1 & 1145 & 1145 & 0 & Towers (mech) \\
\hline Catawba-2 & 1145 & 1145 & 0 & Towers (mech) \\
\hline Cook-1 & 1030 & 1020 & 10 & Lake Michigan \\
\hline Cook-2 & 1100 & 1060 & 40 & Lake Michigan \\
\hline Cooper Station & 778 & 764 & 14 & Missouri R \\
\hline Crystal River-3 & 825 & 821 & 4 & Gulf of Mexico \\
\hline Davis Besse-1 & 906 & 860 & 46 & Tower (natural) \\
\hline Diablo Canyon-1 & 1086 & 1073 & 13 & Pac 0 \\
\hline Diablo Canyon-2 & 1119 & 1079 & 40 & Pac 0 \\
\hline Dresden -2 & 794 & 772 & 22 & Cooling lake \\
\hline Dresden-3 & 794 & 773 & 21 & Cooling lake \\
\hline Ouane Arnold & 538 & 515 & 23 & Tower (mech) \\
\hline Farley-1 & 829 & 827 & 2 & Tower (mech) \\
\hline Farley-2 & 829 & 829 & 0 & Tower (mech) \\
\hline Fitzpatrick & 816 & 796 & 20 & Lake Ontario \\
\hline Fort Calhoun & 478 & 478 & 0 & Missouri R \\
\hline Ginna & 470 & 470 & 0 & Lake Ontario \\
\hline Grand Gulf & 1250 & 1108 & 142 & Towers (natural) \\
\hline Haddam Neck & 582 & 569 & 13 & Connecticut $R$ \\
\hline Hatch-1 & 777 & 768 & 9 & Towers (mech) \\
\hline Hatch-2 & 784 & 777 & 7 & Towers (mech) \\
\hline Hope Creek & 1067 & 1067 & 0 & Towers (mech) \\
\hline
\end{tabular}




\begin{tabular}{|c|c|c|c|c|}
\hline & Rates Mwe & $\begin{array}{l}\text { Maximum } \\
\text { Reliable } \\
\text { Capacity }\end{array}$ & Delta & Type of Cooling \\
\hline Indian Pt-2 & 873 & 864 & $g$ & Hudson R \\
\hline Indian Pt-3 & 965 & 965 & 0 & Hudson R \\
\hline Kewaunee & 535 & 503 & 32 & Lake Michigan \\
\hline LaSalle-1 & 1078 & 1036 & 42 & Reservoir \\
\hline LaSa]le-2 & 1078 & 1036 & 42 & Reservoir \\
\hline Limerick-1 & 1055 & 1055 & 0 & Tower (natural) \\
\hline Main Yankee & 825 & 810 & 15 & Alt 0 \\
\hline McGuire-1 & 1150 & 1150 & 0 & Reservoir \\
\hline McGuire-2 & 1150 & 1150 & 0 & Reservoir \\
\hline Millstone-1 & 660 & 654 & 6 & L I Sound \\
\hline Millistone-2 & 870 & 857 & 13 & L I Sound \\
\hline Millstone-3 & 1154 & 1149 & 5 & L I Sound \\
\hline Monticello & 545 & 536 & 9 & Jowers (mech) \\
\hline Nine Mi le Pt-1 & 620 & 610 & 10 & Lake Ontario \\
\hline North Anna-1 & 907 & 893 & 14 & Reservoir \\
\hline North Anna-2 & 907 & 893 & 14 & Reservoir \\
\hline Oconee-1 & 887 & 860 & 27 & Reservoir \\
\hline Oconee-2 & 887 & 860 & 27 & Reservoir \\
\hline Oconee- 3 & 887 & 860 & 27 & Reservoir \\
\hline Oyster Creek & 650 & 620 & 30 & Barnegat Bay \\
\hline Palisades & 805 & 730 & 75 & Towers (mech) \\
\hline Palo Verde-1 & 1221 & 1221 & 0 & Towers (mech) \\
\hline Palo Verde-2 & 1221 & 1221 & 0 & Towers (mech) \\
\hline Peach Bottom-2 & 1065 & 1051 & 14 & Towers (mech H) \\
\hline Peach Bottom-3 & 1065 & 1035 & 30 & Towers (mech $\mathrm{H}$ ) \\
\hline Pilgrim-1 & 655 & 670 & -15 & Cape Cod Bay \\
\hline Point Beach-1 & 497 & 485 & 12 & Lake Michigan \\
\hline Point Beach-2 & 497 & 485 & 12 & Lake Michigan \\
\hline Prairie Island-1 & 530 & 503 & 27 & Towers (mech) \\
\hline Prairie Island-2 & 530 & 500 & 30 & Towers (mech) \\
\hline Quad Cities-1 & 789 & 769 & 20 & Spray Canal \\
\hline Quad Cities-2 & 789 & 769 & 20 & Spray Canal \\
\hline Rancho Seco & 918 & 873 & 45 & Towers (natural) \\
\hline Robinson-2 & 700 & 665 & 35 & Reservoir \\
\hline Salen-1 & 1090 & 1079 & 11 & Delaware $\mathrm{R}$ \\
\hline Salem-2 & 1115 & 1106 & 9 & Delaware R \\
\hline San Onofre-1 & 436 & 436 & 0 & Pac 0 \\
\hline San Onofre-2 & 1070 & 1070 & 0 & Pac 0 \\
\hline San Onofre-3 & 1080 & 1080 & 0 & Pac 0 \\
\hline Sequoyah-1 & 1148 & 1148 & 0 & Combined cycle \\
\hline Sequoyah-2 & 1148 & 1148 & 0 & Combined cycle \\
\hline
\end{tabular}




\begin{tabular}{|c|c|c|c|c|}
\hline & Rates Mwe & $\begin{array}{l}\text { Maximum } \\
\text { Reliable } \\
\text { Capacity }\end{array}$ & Delta & Type of Cooling \\
\hline St Lucie-1 & 830 & 827 & 3 & Alt 0 \\
\hline St Lucie-2 & 830 & 837 & -7 & Alt 0 \\
\hline Summer & 900 & 885 & 15 & Reservoir \\
\hline Surry-1 & 788 & 781 & 7 & James $\mathrm{R}$ \\
\hline Surry-2 & 788 & 781 & 7 & James R \\
\hline Susquehanna-1 & 1065 & 1032 & 33 & Tower (natural) \\
\hline Susquehanna-2 & 1065 & 1032 & 33 & Tower (natural) \\
\hline TMI -1 & 819 & 776 & 43 & Towers (nat \& mech) \\
\hline Trojan & 1130 & 1075 & 55 & Tower (natural) \\
\hline Turkey Pt-3 & 693 & 666 & 27 & Canals \\
\hline Turkey Pt-4 & 693 & 666 & 27 & Canals \\
\hline Vermont Yankee & 514 & 504 & 10 & Towers \& Conn $\mathrm{R}$ \\
\hline Washington Nuclear-2 & 1100 & 1095 & 5 & Towers (mech) \\
\hline Waterford-3 & 1104 & 1104 & 0 & Mississippi R \\
\hline Wolf Creek-1 & 1170 & 1128 & 42 & Cooling lake \\
\hline Yankee Rowe & 175 & 167 & 8 & Deerfield R \\
\hline Zion-1 & 1040 & 1040 & 0 & Lake Michigan \\
\hline Zion-2 & 1040 & 1040 & 0 & Lake Michigan \\
\hline
\end{tabular}





\section{APPENDIX B}

WET-BULB TEMPERATURE DURATION DATA FOR TWO SITES 


\section{APPENDIX B}

\section{WET-BULB IEMPERATURE DURATION DATA FOR TWO SITES}

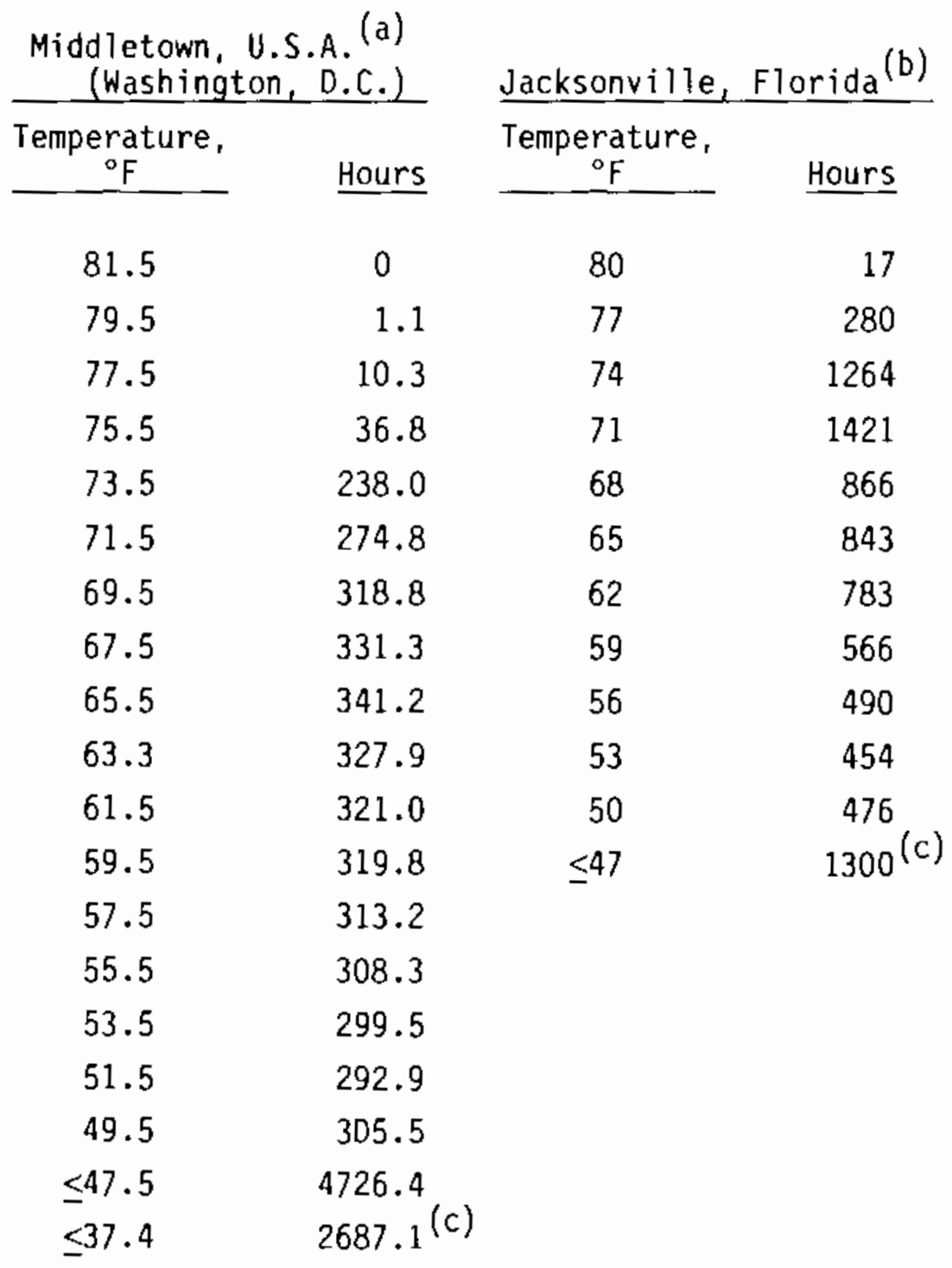

(a) Taken from Drost and Johnson (1980).

(b) Taken from PNL-5143, Vol. 1, weather Data for Simplified Energy Calculation Methods, Volume 1 - Eastern United States TMY Data, August 1984 .

(c) Number of hours greater than hours of suminer operation. 



\section{DISTRIBUTION}

No. of

Copies

OFFSITE

U.S. Department of Energy Attn: K. Klein

Office of Energy Storage \& Dist. Forrestal Bldg, CE-32 5E-036

Washington, DC 20585

U.S. Department of Energy

Attn: E. Reimers

Office of Energy Storage \& Dist.

Forrestal Bldg, CE-32 5E-036

Washington, DC 20585

10 DOE/Office of Scientific and

Technical Information

Argonne National Laboratory

Attn: A. Gorsky

Building 362

9700 S. Cass Avenue

Argonne, IL 60439

Auburn University

Attn: F. J. Molz

School of Engineering

Auburn, AL 36830

Brown and Caldwell

Attn: E. Knipe

150 Arroya Parkway

Pasadena, CA 91109

District Heating Development Co.

Attn: $H$. Jaehne

76 W. Kellogg Blvd.

St. Pau1, MN 55102

Walter Hauz

4520 Via Vistosa

Santa Barbara, CA 93110
No. of

Copies

Lawrence Berkeley Laboratory

Attn: C-F. Tsang

University of California

Bldg. 90, Room 1012-H

1 Cyclotron Road

Berkeley, CA 94720

Charles F. Meyer

1141 Cima Linda Lane

Santa Barbara, CA 93108

Minnesota Geological Survey

Attn: J. Splettstoesser

2642 University Avenue

St. Paul, MN 55114

New York State Energy

Research \& Development Agency

Attn: G. Walmet

Rockefeller Plaza

Albany, NY 12223

Oak Ridge National Laboratory

Attn: J. Tomlinson

Building 9204-1, MS 8045

Y-12 Plant, Box 2009

Oak Ridge, TN 37831-8045

Office of Congressman

Sid Morrison

Attn: Kevin Billings, Legislative Asst. 1330 Longworth B1dg. Washington, DC 20515

Office of Congressman Tom Bevil

2302 Rayburn B1dg.

Washington, DC 20515 
No. of

Copies

Oregon State University

Attn: S. W. Childs

Dept. of Soi1 Science

Corvallis, OR 97331

Resource Efficiency, Inc.

Attn: M. Spurr

340 Daly Street

St. Pau1, MN 55102

Rocket Research Company

Attn: D. D. Huxtable,

Director Energy R\&D

York Center

Redmond, WA 98052

Rocket Research Company

Attn: L. B. Katter

York Center

Redmond, WA 98052

Sandia National Laboratories

Technical Library

Division 3141

Albuquerque, NM 87185

University of Alabama

Attn: E. Brett

School of Mines and Energy Development

Box 6282

University, AL 35486

University of Massachusetts at Amherst

Attn: D. Breger

Dept. of Mechanical Eng.

Eng. Laboratory Bldg.

Amherst, MA 01003

University of Massachusetts at Amherst

Attn: J. E. Sunderland

Dept. of Mechanical Eng.

Eng. Laboratory Bldg.

Anherst, MA 01003
No. of

Copies

University of Minnesota

Attn: M. Hoyer

Underground Space Center

Dept. of Civil and Mineral Eng.

790 Civil and Mineral Eng. Bldg.

Minneapolis, MN 55455

University of Minnesota

Attn: R. L. Sterling

Underground Space Center

Dept. of Civil and Mineral Eng.

790 Civil and Mineral Eng. Bldg

Minneapolis, MN 55455

US Army Corps of Engineers

Attn: C. W. Sohn

Construction Engineering

Research Laboratory

P0 Box 4005

Champaign, IL 61820-1305

US Department of Interior

Attn: Natural Resources

Library

Serials Branch (G/E)

Washington, DC 20240

Wehran Engineering

Attn: R. Miller

666 E. Main St.

P0 Box 2006

Middletown, NY 10940

Wilke and Associates

Attn: D. Wilke

38 Roosevelt Avenue

Gien Head, NY 11545

\section{FOREIGN}

Bengt Hidemark Gosta Danielson Arkitekter SAR

Attn: A. Boysen

Jarntorget 78

S-11 29 Stockholm

Sweden 
No. of

Copies

Commission of European
Communities

Attn: P. Zegers

DG XII, E3

200 Weststraat

Brussels, Belgium

DFVLR

Attn: M. Becker

Bereich Projekttragerschaften

Linder Hohe

5000 Koeln 90

West Germany

DIDIER Werke

Attn: C. Streuber

Lessingstrasse 16-18

D-6200 Wiesbaden 1

West Germany

Helsinki University of Technology

Attn: P. Lund

Otakaari 3

SF-02150 Espoo

Finland

Helsinki University of Technology

Attn: P. Vainio

Otakaari 3

SF-02150 Espoo

Finland

I.E.N.E.R.

EPF-Ecublens

Attn: B. Saugy

1015 Lausanne

Switzerland

IF Technology

Attn: A. Snijders

Fronbregstraat 1

6814 RE Arnhem

The Netherlands

Institut Fisica Universite

Attn: F. Reale

P. le Tecchio

$80125 \mathrm{Napoli}$

Italy
No. of

Copies

Institut fur Kernenergetik und Energiesystems

Attn: M. Groll

Universitat Stuttgart

Pfaffenwaldring 31

Postfach 801140

7000 Stuttgart 80

West Germany

Institut fur Kernenergetik und Energiesystems

Attn: D. Steiner

Universitat Stuttgart

Pfaffenwaldring 31

Postfach 801140

7000 Stuttgart 80

West Germany

Institut fur Technische Physik

Attn: R. Tamme

Deutsche Luft- \& Raumfahrt, e.V.

Pfaffenwaldring 38

7000 Stuttgart 80

West Germany

Institut fur Thermodynamik and Waermetechnik

Attn: U. Gross

Universitat Stuttgart

Pfaffenwaldring 6

7000 Stuttgart 80

West Germany

KFA Julich

Projektleitung Energieforschung

Attn: $F$. J. Friedrich

PO Box 1913

D-5170 Julich

West Germany

KFA Julich, PLE

Attn: V. Lottner

PO Box 1913

D-5170 Julich

West Germany 
No. of

Copies

KM Kjessler \& Mannerstrale $A B$ Attn: $S$. Lundin

PO Box 7124

S-171 07 Solna

Sweden

Laboratory for Energetics

Attn: B. Qvale

Technical University of Denmark

DTH Building 403

DK-2800 Lyngby

Denmark

Management Office for Energy Research PEO

Attn: K. Joon

P. 0. Box 8242

NL-Utrecht

The Netherlands

\section{B. Matthey \\ Consulting-Engineers Ltd. \\ $\mathrm{CH}-2205$ Montezillon-Neuchate 1 \\ Switzerland}

NOVEM

Attn: G. J. van Mourik

PO Box 8242

Leidseveer 35

3503 RE Utrecht

The Netherlands

Public Works Canada

Attn: E. L. Morofsky

C456 Sir Charles Tupper Bldg.

Riverside $\mathrm{Dr}$. and Heron Rd.

Ottawa, Ontario

K1A OM2 Canada

Riso National Laboratory

Attn: P. L. Christensen

DK-4000 Roskilde

Denmark
No. of

Copies

Swedish Council for Building Research

Attn: W. Raldow

St. Goransgatan 66

S-11233 Stockholm

Sweden

Swedish Council for Building Research

Attn: B. T. Sellberg

Sankt Goransgatan 66

S-11233 Stockholm

Sweden

Swiss Federal Energy Office

Attn: A. Fehr

$\mathrm{CH}-3003$ Berne

Switzerland

Universitat Stuttgart

Attn: Rudolf Giebe

Pfaffenwaldring 6

7000 Stuttgart 80

West Germany

ONSITE

DOE Richland Operations office

D. R. Segna, A5-90

32 Pacific Northwest Laboratory

J. M. Bates, K5-21

D. R. Brown, K6-61

M. K. Drost, K5-21 (5)

B. M. Johnson, K5-12

L. D. Kannberg K5-21

G. E. Spanner, K6-61

C. H. Stewart, K5-02

G. M. Stokes, K2-51

P. H. Zimmerman, P7-66

Technical Report Files (5)

Publishing Coordination 